\title{
Review Article \\ Vascular Ageing and Exercise: Focus on Cellular Reparative Processes
}

\author{
Mark D. Ross, Eva Malone, and Geraint Florida-James \\ School of Life, Sport and Social Sciences, Edinburgh Napier University, Edinburgh EH11 4BN, UK \\ Correspondence should be addressed to Mark D. Ross; m.ross@napier.ac.uk
}

Received 30 June 2015; Revised 17 August 2015; Accepted 20 August 2015

Academic Editor: Andreas Daiber

Copyright (C) 2016 Mark D. Ross et al. This is an open access article distributed under the Creative Commons Attribution License, which permits unrestricted use, distribution, and reproduction in any medium, provided the original work is properly cited.

\begin{abstract}
Ageing is associated with an increased risk of developing noncommunicable diseases (NCDs), such as diabetes and cardiovascular disease (CVD). The increased risk can be attributable to increased prolonged exposure to oxidative stress. Often, CVD is preceded by endothelial dysfunction, which carries with it a proatherothrombotic phenotype. Endothelial senescence and reduced production and release of nitric oxide (NO) are associated with "vascular ageing" and are often accompanied by a reduced ability for the body to repair vascular damage, termed "reendothelialization." Exercise has been repeatedly shown to confer protection against CVD and diabetes risk and incidence. Regular exercise promotes endothelial function and can prevent endothelial senescence, often through a reduction in oxidative stress. Recently, endothelial precursors, endothelial progenitor cells (EPC), have been shown to repair damaged endothelium, and reduced circulating number and/or function of these cells is associated with ageing. Exercise can modulate both number and function of these cells to promote endothelial homeostasis. In this review we look at the effects of advancing age on the endothelium and these endothelial precursors and how exercise appears to offset this "vascular ageing" process.
\end{abstract}

\section{The Endothelium in Health and Disease}

The endothelium controls diffusion and transport of nutrients, gases, and other signalling molecules from the blood into the surrounding tissues and controls adhesion, rolling, and migration of leukocytes to sites of infection and tissue damage. The endothelium also controls blood flow distribution around the body through the release of vasoactive substances, including nitric oxide (NO) and prostacyclin $\left(\mathrm{PGI}_{2}\right)$ [1]. Under normal conditions, $\mathrm{NO}$ is released from the endothelium, which diffuses to the vascular smooth muscle, causing the smooth muscle cells to relax, thus widening the diameter of the blood vessel, allowing more blood to flow distally to that vessel, a process termed endothelial function. $\mathrm{NO}$ is not only vasoactive to control vessel lumen diameter, but also antiatherogenic, inhibiting platelet and leukocyte adhesion to the endothelium [2].

Endothelial dysfunction often precedes CVD, and the ability of the endothelium to produce and release NO, measured as flow-mediated dilatation (FMD), can be predictive of future cardiovascular events [3] and mortality [4], potentially due to those with endothelial dysfunction being susceptible to atheroma formation and progression. Therefore the endothelium is a key player in maintenance of vascular health.

\section{The Ageing Endothelium Role of Oxidative Stress}

Advancing age is associated with endothelial dysfunction [512 ], increased susceptibility of endothelial cells to apoptosis $[13,14]$, and altered intracellular signalling [8]. These have been linked to NO bioavailability [15-17] and chronic exposure to oxidative stress $[9,18-20]$, which is an imbalance between the production of free radicals (oxidants) and opposing antioxidants, of which the greater production or presence of oxidants than antioxidants results in tissue damage and cellular dysfunction. Indeed the bioavailability of NO itself is a product of the rate of $\mathrm{NO}$ production and its scavenging by free radicals. Free radicals, such as superoxide anions $\left(\mathrm{O}_{2}{ }^{\cdot-}\right)$, 
have been found in greater levels in aged vascular tissue of rats compared to their younger counterparts [21], as well as in other models of ageing [22, 23], and levels of reactive oxygen species (ROS) derived from NADPH oxidase account for attenuated endothelial-dependent vasodilation in aged mice [24]. Scavenging or inhibition of these radicals improves endothelium function $[15,21]$. The increased production of $\mathrm{O}_{2}{ }^{--}$and NO leads to the formation of peroxynitrite $[15,25]$ and the subsequent uncoupling of eNOS [15]. In contrast to this, Luttrell et al. [26] observed high eNOS content within aortic rings of old versus young rats despite reduced endothelial function, a potential compensatory mechanism to increase the drive for NO production.

Oxidative stress can also promote atherosclerosis through the oxidation of low-density lipoprotein (oxLDL), which can stimulate macrophages to migrate from the circulation into the vascular wall [27], progressing to the development of foam cells, which is a key process in the formation of an atherosclerotic lesion. OxLDL also exerts deleterious effects on the vascular smooth muscle cell wall, by stimulating inflammatory cytokine release (tumour-necrosis factor- $\alpha$, TNF- $\alpha$, and monocyte chemoattractant protein-1, MCP-1) [28]. In fact, circulating oxLDL has been shown to be a predictor of cardiovascular events in humans [29], confirming its association with vascular health.

In addition to increased production of oxidants, there may be a concomitant reduction or impairment in antioxidant defences with ageing resulting in prooxidants going unchecked causing damage to surrounding tissues and accelerating ageing. For example, plasma concentration of one such antioxidant enzyme, superoxide dismutase (SOD), which itself catalyzes the dismutation of $\mathrm{O}_{2}{ }^{--}$into oxygen and hydrogen peroxide, declines with age. This reduction was however not found in cellular tissue $[11,30]$, which itself may suggest that ageing may be associated with increased production of ROS rather than an impairment of cellular antioxidant capacity. Yet one study has found impaired activities of various antioxidant enzymes in aged cardiovascular tissue in rats [31]. More studies are required to fully elucidate the effects of age in animals and humans on antioxidant capacity. Acute administration of antioxidants, provided by vitamin $\mathrm{C}$ and SOD mimetics, can improve NO bioavailability and endothelial function $[9,32,33]$, therefore offering the potential to reduce tissue damage via dietary means. This is not within the scope of this review, but for a review of this see Brown and $\mathrm{Hu}$ [34].

Sirtuin 1 (SIRT1) is a protein involved in DNA repair, cell cycle regulation, and ageing [35]. It functions to catalyze the removal of acetyl groups attached to lysine residues of various molecules involved in cellular signalling [36]. It is expressed in endothelial cells and has been observed to play a key role in prevention of endothelial cell senescence [37-39] by modulating p53 expression [39] and P66Shc [37], both of which are involved in oxidative stress-induced senescence. SIRT1 expression and activity are reduced in aged endothelial cells [40], but by increasing the expressing of SIRT1, endothelial senescence can be prevented [38, 41]. It appears that SIRT1 also plays a protective role in preventing ROS production in endothelial cells, as activating
SIRT1 pharmacologically prevents ROS-induced endothelial dysfunction [42]. In addition, inhibition of SIRT1 caused an increase in NADPH oxidase activity and the associated $\mathrm{O}_{2}{ }^{--}$ production [42], which can go on to inactivate NO [21]. SIRT1 is therefore an important regulator of vascular endothelial ageing.

In addition to loss of NO bioavailability with ageing, there has been documented evidence of loss of prostacyclinmediated dilatation of vasculature in humans [43] potentially as a result of reduced prostacyclin production $[44,45]$. However, under NO inhibition, the dilatory response to prostacyclin in young and old subjects was similar [43], implicating loss of the NO pathway as the primary mechanism behind ageing-induced vascular dysfunction.

\section{Exercise and the Endothelium}

Physical activity and regular exercise training has been shown to play a significant role in the prevention of CVD, in addition to reducing the risk of mortality [46-58]. The reverse can be seen with physical inactivity and sedentary lifestyle associated with increased risk of NCD and mortality [59-68]. Physical activity and regular exercise training is antiatherogenic [69] and reduces oxidative stress through upregulation of antioxidants, such as SOD [70, 71]. Exercise has been shown to increase mitochondrial manganese SOD and cytosolic $\mathrm{Cu} / \mathrm{Zn} \mathrm{SOD}$ isoforms [72] which may contribute to a reduction in oxidative stress in the endothelium. There is a plethora of studies showing the beneficial effects of exercise on FMD, indicating improved endothelial function $[5,6,12,73-81]$. On the other hand, sedentary interventions (reducing step counts and increasing sitting time or bed rest studies) result in the opposite effect on FMD [8284]. Exercise and periodic increases in physical activity result in increases in cardiac output and greater blood flow through the vasculature. The increase in flow across the endothelium generates a shear stress stimulus, which is the shearing effect of circulating cells across the endothelium. Greater levels of laminar shear stress, as observed during exercise, result in an increase in NO production and release by the endothelium to widen the vessel diameter. Birk et al. [85] investigated the role of shear stress on the vascular adaptation to exercise. They observed that, in individuals who exercised for 8 weeks, brachial artery dilatory response was greater in the arm that was unrestricted to blood flow, whereas, in the arm that was restricted to blood flow via an arm inflatable cuff, there was no significant change in endothelial-dependent dilatation. Therefore shear stress is a key stimulus for vascular adaptation during an exercise training programme. The improved endothelial function can be attributable to increased endothelial NO synthase (eNOS) protein levels within the endothelium as evidenced from mice models $[19,72]$ and/or reduced oxidative stress $[19,72,76,86]$. The reduced oxidative stress can help prevent the uncoupling of NO, therefore increasing NO bioavailability. One study has however shown no changes in eNOS protein content as a result of exercise training [86]. The effects of ageing and exercise on the endothelium are summarised in Figure 1. 


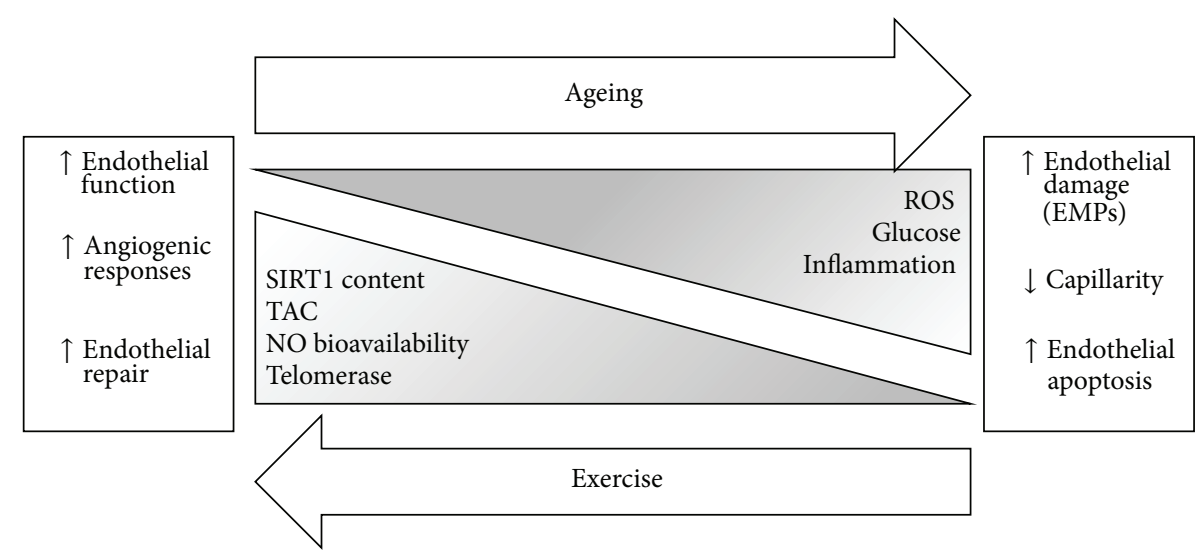

FIGURE 1: The effect of age and exercise on the endothelium. SIRT1: Sirtuin 1, TAC: total antioxidant capacity, NO: nitric oxide, ROS: reactive oxygen species, and EMP: endothelial microparticles.

\section{Endothelial Precursors: New Cellular Markers of Endothelial Regeneration}

The endothelium is reported to have a turnover rate of between 47 and 23,000 days using continuous labelling techniques [87]. However, endothelial cell turnover may be higher in areas of bifurcations [88], potentially as a result of disturbed flow [89], and increases in oxidative stress [90]. It was thought that normal endothelial cell turnover was maintained by proliferation of resident endothelial cells; however, recently, the contributions of stem cell-like cells have been described, as also seen with skin [91] and skeletal muscle [92]. Endothelial precursors or endothelial progenitor cells (EPCs) were discovered in 1997 by Asahara et al. [93]. Researchers observed that isolated $\mathrm{CD} 34^{+}$cells from human peripheral blood formed tube-like structures on fibronectincoated plates in vitro. These cells, after a period of 7 days in culture, began to express endothelial lineage markers such as VEGFR2, PECAM-1, and E-selectin and stained positively for eNOS. These CD $34^{+}$cells also secreted NO under stimulation by vascular endothelial growth factor (VEGF) or acetylcholine, a key characteristic of mature endothelial cells. These EPCs have been consistently shown to repair damaged endothelium in animal [93-95] and human studies [96-98]; however, these endothelial precursors are rare events in human peripheral blood, accounting for only between 0.0001 and $0.01 \%$ of all mononuclear cells [99], with this level varying depending on age and health status [100]. Tissue damage may stimulate a mobilisation of $\mathrm{CD}_{3} 4^{+}$progenitors, which may increase the circulating number of these cells by up to $500 \%(0.01 \%$ to $0.50 \%$ of all mononuclear cells) [101]. EPCs may make up a substantially smaller number in circulating pool and may only make up $10 \%$ of $\mathrm{CD}^{+} 4^{+}$ progenitors [102].

There is some debate on the origin of these endothelial precursors. There is clear evidence showing that they are likely derived from the bone marrow [94, 95]. Some researchers have suggested that EPCs are resident in the vessel wall, with adventitia-resident $\mathrm{CD} 34^{+}$progenitors able to promote vessel formation in vitro [111] and in vivo [96].
However, Passman et al. [112] failed to observe endothelial differentiation of adventitial progenitors, with these cells instead taking a more vascular smooth muscle cell phenotype. It may be that the vascular growth and reparative process involves both circulating cells derived from the bone marrow and vascular-resident cells, promoting the proliferation of endothelial cells through paracrine means via the secretion of VEGF and also through differentiation into mature endothelial cell phenotype.

There appears to be 2 subsets of EPCs, each subset playing a different role in vascular regeneration and repair. These have been termed "early" and "late" outgrowth cells and named so because of their appearance in culture. The so-called "early" EPCs appear early in culture and die after 4 weeks. These cells secrete relatively large amounts of proangiogenic cytokines and growth factors such as VEGF and interleukin-8 (IL-8), whereas the "late" EPCs appear late in culture, live up to 12 weeks, produce more NO than "early" EPCs, and formed capillary structures to a greater extent than "early" EPCs [113]. It can be concluded that "late" EPCs have greater ability to differentiate into endothelial cells, whereas "early" EPCs have greater potential to promote vascular repair in a paracrine manner.

\section{Endothelial Progenitor Cells and Vascular Disorders}

Many studies have found that those with vascular-related disorders have reduced circulating number and/or impaired function of EPCs compared to healthy age-matched controls [114-138]. Numbers are also associated with endothelial function [116, 131], implicating the role of EPCs in maintaining endothelial health. Circulating "late" EPCs have also been shown to be predictive of mortality incidence, with those with higher numbers having a lower mortality rate than those with low circulating levels [139].

Paradoxically, Pelliccia et al. [140] found that those with high levels of CD $34^{+} \mathrm{CD} 45^{-}$VEGFR2 ${ }^{+}$cells were more likely to suffer a cardiovascular event within 5 years of followup after undergoing percutaneous coronary intervention. 
These findings may be attributable to the potential role of EPCs in the progression of atherosclerosis [126]. EPCs may contribute to atherosclerotic development through secretion of proinflammatory factors such as plasminogen activator inhibitor 1 (PAI-1) and monocyte chemoattractant protein-1 (MCP-1) [141]. Both are involved in atherosclerosis, with PAI1 expressed within plaques, with more expression in increasingly progressed plaques [142], and with MCP-1 involved in the adhesion of monocytes to the vascular wall [143]. EPCs' secreting these proinflammatory mediators of atherosclerosis is a surprising function and paves the way for the potential role of EPCs in atherosclerosis development and progression. However there are some reports linking EPCs to the prevention of atherosclerosis, either by inverse relationships between number/function and atherosclerotic lesion development [119] or by infusion of these cells potentially causing reduced plaque burden or attenuation of plaque progression $[144,145]$. Additional research is needed to fully elucidate the role in atherosclerosis development or prevention.

In the studies that show reduced circulating number of EPCs with vascular-related disorders, this reduction could be as a direct result of bone marrow depletion of these cells, due to an increased requirement for vascular repair. Mobilization of these cells by VEGF in mice has been found to reduce the number of both haematopoietic and mesenchymal stem/progenitor cells within the bone marrow after only 5 days [146]. In addition critical limb ischemia patients display reduced circulating EPCs as well as a reduced number of bone marrow resident $\mathrm{CD} 34^{+}$cells compared to healthy controls [132].

The observed reduction in circulating progenitor number in those with vascular disease may also be attributable to an impaired mobilization process. Matrix metalloproteinase- 9 (MMP-9) activity in the bone marrow of critical ischemia patients is reduced accompanying a reduced circulating and bone marrow resident $\mathrm{CD} 34^{+}$cell number [132]. MMP-9 is involved in the mobilization of progenitors from the bone marrow [147-149], believed to be specifically involved in cleaving stromal-derived factor-1 (SDF-1, ligand for C-X-C Chemokine Receptor 4; CXCR4) allowing CXCR4 ${ }^{+}$progenitor cells free to leave the bone marrow [150]. Diabetics, both type I and type II, also appear to have reduced circulating EPC numbers compared to healthy controls [120,131, 151-156], in part due to impaired mobilization. Type II diabetics present with a reduction in capillarity within the bone marrow, which was associated with the duration of the diabetes, as well as fasting glucose levels [155], with a possible consequence of inadequate nutrient delivery for progenitor or stem cell production within the bone marrow. This could implicate impaired progenitor cell maintenance in addition to impaired mobilization.

\section{Ageing and Endothelial Progenitor Cells}

As discussed, ageing is associated with endothelial dysfunction, as well as impaired angiogenesis [157-161]. These effects could be associated with a reduction in EPC numbers or impaired function of these vasculogenic cells. Age does in fact result in reduced circulating EPCs $[104,106]$ and impaired function as displayed as reduced migration and proliferation $[97,98,103,105,106,109,110]$ (Table 1). In two studies, migration and proliferation of EPCs were independent predictors of endothelial function in both young and old individuals $[103,104]$.

Xia et al. $[97,98]$ used in vivo mouse models to investigate the effect of age and the ability of human "early" EPCs to repair damaged endothelium. The authors induced carotid artery injury in mice and found that the ability of the mice to repair the endothelium was age-dependent. The mice that received the "young" EPCs (EPCs isolated from young individuals) displayed a greater ability to repair the endothelium in comparison to those that received the "old" EPCs (EPCs isolated from old individuals). Based on the morphological appearance of these cells being "early" EPCs, it is likely that these cells promoted reendothelialization mainly via paracrine means [113]. This in vivo model was accompanied by in vitro age-related impairments in EPC migration and adhesion of these cells. The authors reported that, under stimulation by SDF-1, these "old" cells failed to phosphorylate Janus Kinase-2 (JAK-2) to the same extent as "young" EPCs, despite similar CXCR4 cell surface expression between the two age groups, implicating a disrupted intracellular signalling mechanism as the reason by which these cells become dysfunctional, rather than cell surface protein expression changes.

EPCs from old individuals may also display impaired paracrine action, as found by Kushner et al. [108], who observed reduced release of granulocyte colony-stimulating factor (G-CSF) after stimulation by the stimulant phytohemagglutinin (PHA). However, the stimulated release of IL8 , another proangiogenic cytokine, was not different between young and old individuals. Therefore, paracrine action of these cells and their ability to stimulate endothelial repair by signalling endothelial cells to proliferate may be hindered with age.

The same group measured telomere length in EPCs isolated from peripheral blood mononuclear cells (PBMNC) in another study. Telomeres are repetitive DNA sequences (TTAGGG) at the end of chromosomes, and they act to protect DNA from damage. Replication of cells causes the length of telomeres to shorten, and therefore telomere length has often been used as a biomarker for cellular/biological age $[107,162,163]$. Repeated rounds of division and replication may cause cells to become senescent (cells are unable to replicate further). Telomere length, as measured using genomic DNA preparation and Southern hybridization techniques in EPCs isolated from PBMNC from old compared to young individuals, was shorter; however, they were not different between young and middle-aged individuals [107]. The participants in this study were reported to be healthy men, with no history of CVD or diabetes, further strengthening the belief that these cells are affected not only by disease, but also by ageing. Recent evidence suggests that telomeres can be deleteriously impacted upon by ROS. In an ageing model using $n f k b 1$ knockout mice, fibroblasts that show accelerated ageing also display reduction in telomere length, yet this effect was attenuated by antioxidant treatment of the mice 
TABLE 1: Effect of age on EPC number and function.

\begin{tabular}{|c|c|c|c|}
\hline Reference & Subject population & EPC assay & Finding \\
\hline $\begin{array}{l}\text { Heiss et al., } \\
2005 \text { [103] }\end{array}$ & $\begin{array}{l}20 \text { young }(\sim 25 \mathrm{yr}) \text { men } \\
20 \text { old }(\sim 61 \mathrm{yr}) \text { men }\end{array}$ & $\begin{array}{l}\mathrm{CD} 34^{+} \mathrm{VEGFR}^{+} \text {, } \\
\mathrm{CD} 133^{+} \text {VEGFR2 }{ }^{+} \text {cells }(\mathrm{FC}) \\
\text { EPC CFU } \\
\text { EPC migration }\end{array}$ & $\begin{array}{l}\text { (i) No difference in EPC number between age } \\
\text { groups } \\
\text { (ii) Reduced EPC migration and proliferation } \\
\text { in old versus young men }\end{array}$ \\
\hline $\begin{array}{l}\text { Thijssen } \\
\text { et al., } 2006 \\
{[104]}\end{array}$ & $\begin{array}{l}16 \text { young }(19-28 \text { yr }) \text { men } \\
8 \text { old }(67-76 \mathrm{yr}) \text { men }\end{array}$ & $\mathrm{CD} 4^{+} \mathrm{VEGFR}^{+}$cells (FC) & EPC reduced in old versus young men \\
\hline $\begin{array}{l}\text { Hoetzer } \\
\text { et al., } 2007 \\
{[105]}\end{array}$ & $\begin{array}{l}10 \text { young }(22-35 \mathrm{yr}) \text { men } \\
15 \text { middle-aged } \\
(36-55 \mathrm{yr}) \text { men } \\
21 \text { old }(56-74 \mathrm{yr}) \text { men }\end{array}$ & $\begin{array}{l}\text { EPC CFU } \\
\text { EPC migration }\end{array}$ & $\begin{array}{l}\text { (i) Reduced proliferation in middle-aged and } \\
\text { older versus young men } \\
\text { (ii) Reduced migration in old versus } \\
\text { middle-aged and young men }\end{array}$ \\
\hline $\begin{array}{l}\text { Thum et al., } \\
2007 \text { [106] }\end{array}$ & $\begin{array}{l}10 \text { young }(23-31 \text { yr }) \text { men } \\
16 \text { middle-aged } \\
(50-69 \text { yr }) \text { men } \\
12 \text { old }(\sim 74 \text { yr }) \text { men. }\end{array}$ & $\begin{array}{l}\text { CD } 133^{+} \text {VEGFR2 }{ }^{+} \text {cells }(\mathrm{FC}) \\
\text { EPC migration } \\
\text { eNOS content of EPC }\end{array}$ & $\begin{array}{l}\text { EPC numbers, migration, and eNOS content } \\
\text { reduced in old versus young and middle-aged } \\
\text { versus young men }\end{array}$ \\
\hline $\begin{array}{l}\text { Kushner } \\
\text { et al., } 2009 \\
{[107]}\end{array}$ & $\begin{array}{l}12 \text { young }(21-34 \mathrm{yr}), 12 \\
\text { middle-aged }(43-55 \mathrm{yr}) \\
\text { and } 16 \text { old }(57-68 \mathrm{yr}) \\
\text { men }\end{array}$ & Telomere length of isolated EPCs & $\begin{array}{l}\text { EPC telomere length significantly reduced in } \\
\text { older versus middle-aged and young men }\end{array}$ \\
\hline $\begin{array}{l}\text { Kushner } \\
\text { et al., } 2010 \\
{[108]}\end{array}$ & $\begin{array}{l}17 \text { young }(21-34 \mathrm{yr}) \text { men } \\
20 \text { old }(56-70 \mathrm{yr}) \text { men }\end{array}$ & $\begin{array}{l}\text { EPC release of proangiogenic } \\
\text { factors: G-CSF, VEGF, IL-8, and } \\
\text { IL-17 }\end{array}$ & $\begin{array}{l}\text { EPC release of G-CSF impaired in old versus } \\
\text { young men }\end{array}$ \\
\hline $\begin{array}{l}\text { Xia et al., } \\
2012 \\
{[97,98]}\end{array}$ & $\begin{array}{l}25 \text { young }(\sim 26 \mathrm{yr}) \text { men } \\
22 \text { old }(\sim 68 \mathrm{yr}) \text { men }\end{array}$ & $\begin{array}{l}\text { CD } 34^{+} \text {VEGFR } 2^{+} \text {cells (FC) } \\
\text { Mouse model of carotid injury } \\
\text { and infusion of EPCs from young } \\
\text { or old men. } \\
\text { As above }+ \\
\text { EPC migration } \\
\text { EPC adhesion assay }\end{array}$ & $\begin{array}{l}\text { (i) EPC numbers reduced in old versus young } \\
\text { men } \\
\text { (ii) Reduced endothelial repair capacity in } \\
\text { mouse model in old versus young men } \\
\text { (iii) Reduced CXCR4:JAK-2 signalling in old } \\
\text { versus young men } \\
\text { (iv) EPC adhesion to endothelial monolayer } \\
\text { impaired in old versus young men } \\
\text { (v) Reduced EPC migration in old versus } \\
\text { young men }\end{array}$ \\
\hline $\begin{array}{l}\text { Williamson } \\
\text { et al., } 2013 \\
{[109]}\end{array}$ & $\begin{array}{l}4 \text { young }(20-30 \mathrm{yr}) \\
\text { individuals } \\
4 \text { old }(50-70 \mathrm{yr}) \\
\text { individuals }\end{array}$ & $\begin{array}{l}\text { EPC CFU } \\
\text { EPC migration }\end{array}$ & $\begin{array}{l}\text { (i) No difference in proliferation between } \\
\text { young and old individuals } \\
\text { (ii) Reduced migration in old versus young } \\
\text { individuals }\end{array}$ \\
\hline $\begin{array}{l}\text { Yang et al., } \\
2013 \text { [110] }\end{array}$ & $\begin{array}{l}20 \text { young }(21-33 \mathrm{yr}) \text { men } \\
20 \text { old }(59-72 \mathrm{yr}) \text { men }\end{array}$ & $\begin{array}{l}\mathrm{CD} 34^{+} \text {VEGFR } 2^{+} \text {cells }(\mathrm{FC}) \\
\text { EPC migration }\end{array}$ & $\begin{array}{l}\text { Reduced number and migration of EPCs in } \\
\text { sedentary old versus sedentary and endurance } \\
\text { trained young, no difference in endurance } \\
\text { trained old versus young men }\end{array}$ \\
\hline
\end{tabular}

FC: flow cytometry, CFU: colony forming units.

[164]. However, data is lacking with respect to circulating progenitor cells.

Once again, oxidative stress may play a central role in the ageing effect on progenitor cell number and function. $\mathrm{CD} 34^{+}$progenitors in male and female octogenarians were inversely correlated with circulating levels of ROS, and those individuals who had died by the end of the follow-up (7 years) had significantly higher levels of ROS at baseline [165], highlighting the importance of reducing oxidative stress and related damage for longevity. Indeed circulating levels of ROS are greater in aged humans than young humans, and this is also accompanied by a decreased EPC content of SIRT1, which may allow ROS damage to continue unchecked. SIRT1 administration to EPCs in vitro rescues EPCs from
$\mathrm{H}_{2} \mathrm{O}_{2}$-induced apoptosis [166], and SIRT1 deletion leads progenitor cells to exhibit an ageing phenotype as indicated by an increase in DNA damage and increased intracellular content of ROS [167]. These observations lead us to believe that the process of ageing, through the increased production of ROS, and reduced SIRT1 content of EPCs, could lead, partially, to the reduced number and function of these vascular regenerative cells, increasing risk for CVD in ageing individuals.

The evidence points to a deleterious effect of ageing on the ability of the body to stimulate endothelial repair, through depletion of EPC number, in both circulation and bone marrow, as well as impairment of function of these cells. Ageing is associated with increased risk of NCDs [168], 
and the effect of age on EPCs may be a causative factor. It is therefore of great importance to maintain EPC number and function throughout the lifespan in order to reduce risk of these NCDs. There is plenty of evidence to show that pharmaceutical interventions, such as statins [169-176], can help maintain EPC number and function; however this places a large financial burden on health services, thus addressing other lifestyle factors, such as diet, and exercise may be more cost effective.

\section{Exercise and Endothelial Progenitor Cells}

Regular exercise has been consistently shown to be beneficial for health. Exercise can improve cardiorespiratory fitness, lower blood pressure $[177,178]$, improve left ventricular function $[133,179]$, reduce chronic low-grade inflammation [180], improve tissue perfusion [181], reduce fasting blood glucose [182], and increase insulin sensitivity [183]. Taken together, there is overwhelming evidence that regular exercise or having a higher level of cardiorespiratory fitness can offer some protection against NCD incidence and mortality [4758]. Recently, there has been a growth in interest in EPC biology and the impact of exercise on these cells.

Acute exercise has been repeatedly shown to mobilize EPCs into the circulation in addition to enhancing the in vitro and in vivo function of these cells for a period of up to 72 hours, depending on the intensity and duration of the bout of exercise investigated [134, 184-202], with few studies showing no changes $[104,203]$ or even reductions in progenitors after exercise [204]. The observed increases in circulating angiogenic progenitors are often seen alongside increases in circulating SDF-1 [187], VEGF [184, 191, 193, 194], G-CSF, MMP-9 [193], or increased NO production [202]. Acute maximal exercise bout has been shown to improve the function of EPCs, as measured by increased migratory capacity to VEGF and SDF-1 in vitro [134] which is proposed to aid in the cells being able to migrate to ischaemic tissue to stimulate vessel growth. The improved function of these cells may be due to increases in CXCR4 cell surface expression, yet this has yet to be investigated in EPCs. Exercise-induced increases in circulating cortisol have been found to increase CXCR4 expression in T-lymphocytes [205] indicating that the circulating environment that these cells are exposed to as a result of exercise may affect cell surface receptor expression and subsequently function. Increased CXCR4 cell surface expression could also be stimulated by increases in shear stress [97] caused by increases in cardiac output seen with exercise. Further study is required to investigate the effect of acute exercise and the role CXCR4 plays in postexercise improvements in EPC migratory function. Age also appears to have an impact on the acute exercise response. EPC numbers increased in circulation in old individuals; however, this response was attenuated in comparison to a young population [200] suggesting an impaired mobilisation process.

Regular exercise training also results in increases in resting EPC numbers [98, 105, 110, 206-220], potentially contributing to the observed improvement in endothelial function with exercise [219]. However, some studies have found no changes in circulating number but did find improvements in in vivo endothelial-repair ability [98], in vitro endothelial colony forming unit ability [215], or in vitro NO production [218]. Xia et al. [98] investigated the effect of regular exercise training on EPC-mediated endothelial repair using a murine model of carotid artery injury. Before and after exercise training (30 minutes per day, 3 days per week, and 12 weeks of aerobic exercise) human "early" EPCs were isolated and cultured. These cells were then injected into left carotid artery of athymic nude mice after carotid injury. Endothelial regeneration was greater in the mice injected with EPCs from young subjects compared to those injected with EPCs from older subjects. Endothelial regenerative ability of these cells was improved in the older men after the 12-week training period. The improvement in EPC in vivo function as a result of the exercise training period in humans was associated with improvements in intracellular signalling, with increased signalling between CXCR4 and its downstream target, Janus Kinase-2 (JAK2) [98], a potential mechanism for the improved migratory capacity of these cells after training interventions [134]. Other functional improvements seen with exercise training include improved migration to VEGF [105, 217, 220] and SDF-1 [220], adhesion to human umbilical cord vein endothelial cells [98], and secretion of NO [218]. Importantly these improvements in EPC function and/or number have been found to be related to the improvement seen in endothelial function as a result of an exercise training program [219], potentially implicating these cells in the process of improving endothelial function with exercise. The effects of age and exercise on these progenitor cell subsets and their effect on the endothelium is summarised in Figure 2.

Other mechanisms behind improved number and function of these cells with exercise training are potentially linked to reduced oxidative stress which affect progenitor cell function [166] and lower fasting blood glucose, as hyperglycaemic conditions typically affect progenitor cell functions [152, 221].

Detraining and inactivity on the other hand play a role in reducing vascular regenerative capacity of these cells. Only 10-day detraining was sufficient to reduce $\mathrm{CD}_{3} 4^{+}$and CD $34^{+}$VEGFR2 ${ }^{+}$progenitor cells, and the extent of decline in EPCs (CD34 $4^{+}$VEGFR2 ${ }^{+}$) was associated with the decline in endothelial function [222]. Additionally, these cells at baseline were associated with oxLDL plasma concentrations. The observed increase in EPC senescence potentially resulted from a reduction in total antioxidant capacity of the individual, which concomitantly decreased after the 10-day detraining. Data from this study suggest that oxidative stress and antioxidant capacity of the individual may be associated with physical activity and as a result may modulate EPC number and senescence and subsequent endothelial function and cardiovascular risk.

\section{Summary}

The process of ageing is often associated with increased morbidity and mortality. "Vascular ageing" represents 


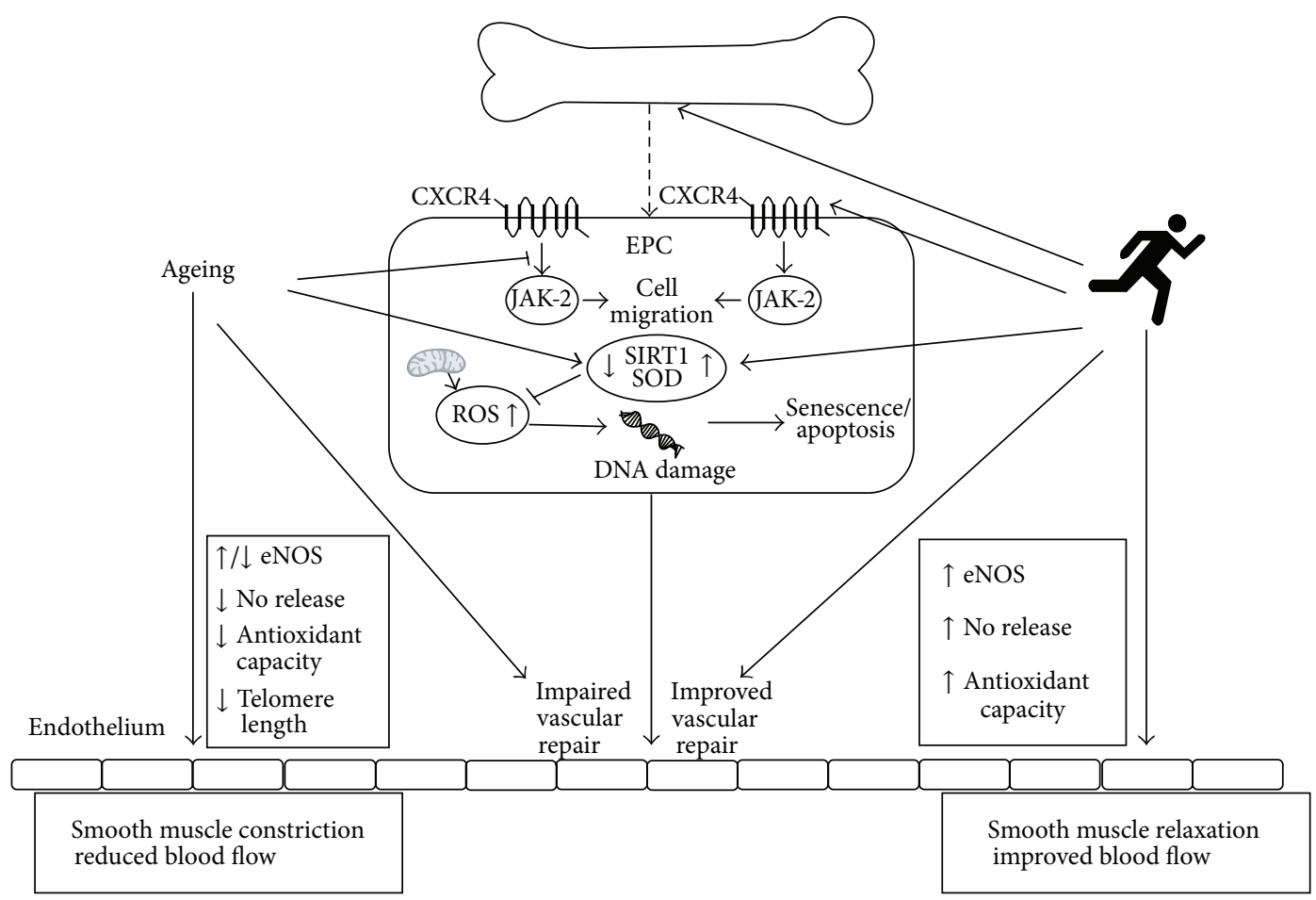

FIGURE 2: The effects of age and exercise on EPC-mediated vascular repair and endothelial function. Ageing causes the reduced signaling between CXCR4 and Janus Kinase-2 (JAK-2), as well as being associated with a reduced antioxidant capacity. Exercise mobilizes EPCs from bone marrow and rescues the signaling between CXCR4 and JAK-2, as well as stimulating production of antioxidants Sirtuin 1 (SIRT1) and superoxide dismutase (SOD). EPC-mediated repair of endothelium leads to improved endothelial function.

the multitude of effects of ageing on the vascular tree including endothelial dysfunction, increased arterial stiffness, atherosclerotic plaque formation, and an impaired angiogenic response. Exercise training may offset this process of "vascular ageing" by maintaining or improving EPC number and function, which can then act to help maintain endothelial function through paracrine signalling to promote endothelial proliferation or by adhering to the vessel wall and differentiating into mature endothelial cells, with fully functional eNOS and high NO content. The reduction in oxidative stress as seen following exercise training programs may also promote EPC survival and prevent functional decline of these cells with age.

\section{Conflict of Interests}

The authors declare that there is no conflict of interests regarding the publication of this paper.

\section{References}

[1] R. F. Furchgott and J. V. Zawadzki, "The obligatory role of endothelial cells in the relaxation of arterial smooth muscle by acetylcholine," Nature, vol. 288, no. 5789, pp. 373-376, 1980.

[2] J. P. Cooke and P. S. Tsao, "Is NO an endogenous antiatherogenic molecule?" Arteriosclerosis and Thrombosis, vol. 14, no. 5, pp. 653-655, 1994.
[3] D. J. Green, H. Jones, D. Thijssen, N. T. Cable, and G. Atkinson, "Flow-mediated dilation and cardiovascular event prediction," Hypertension, vol. 57, no. 3, pp. 363-369, 2011.

[4] M. Shechter, S. Matetzky, M. Arad, M. S. Feinberg, and D. Freimark, "Vascular endothelial function predicts mortality risk in patients with advanced ischaemic chronic heart failure," European Journal of Heart Failure, vol. 11, no. 6, pp. 588-593, 2009.

[5] M. A. Black, N. T. Cable, D. H. J. Thijssen, and D. J. Green, "Impact of age, sex, and exercise on brachial artery flowmediated dilatation," The American Journal of PhysiologyHeart and Circulatory Physiology, vol. 297, no. 3, pp. H1109H1116, 2009.

[6] M. A. Black, D. J. Green, and N. T. Cable, "Exercise prevents agerelated decline in nitric-oxide-mediated vasodilator function in cutaneous microvessels," The Journal of Physiology, vol. 586, no. 14, pp. 3511-3524, 2008.

[7] J. M. Muller-Delp, "Aging-induced adaptations of microvascular reactivity," Microcirculation, vol. 13, no. 4, pp. 301-314, 2006.

[8] K. G. Soucy, S. Ryoo, A. Benjo et al., "Impaired shear stressinduced nitric oxide production through decreased NOS phosphorylation contributes to age-related vascular stiffness," Journal of Applied Physiology, vol. 101, no. 6, pp. 1751-1759, 2006.

[9] S. Taddei, A. Virdis, L. Ghiadoni et al., "Age-related reduction of NO availability and oxidative stress in humans," Hypertension, vol. 38, no. 2, pp. 274-279, 2001.

[10] R. D. Prisby, M. W. Ramsey, B. J. Behnke et al., "Aging reduces skeletal blood flow, endothelium-dependent vasodilation, and no bioavailability in rats," Journal of Bone and Mineral Research, vol. 22, no. 8, pp. 1280-1288, 2007. 
[11] A. J. Donato, I. Eskurza, A. E. Silver et al., "Direct evidence of endothelial oxidative stress with aging in humans: relation to impaired endothelium-dependent dilation and upregulation of nuclear factor- $\kappa$ B," Circulation Research, vol. 100, no. 11, pp. 1659-1666, 2007.

[12] S. A. Spier, M. D. Delp, C. J. Meininger, A. J. Donato, M. W. Ramsey, and J. M. Muller-Delp, "Effects of ageing and exercise training on endothelium-dependent vasodilatation and structure of rat skeletal muscle arterioles," The Journal of Physiology, vol. 556, no. 3, pp. 947-958, 2004.

[13] H. Wang, A. Listrat, B. Meunier et al., "Apoptosis in capillary endothelial cells in ageing skeletal muscle," Aging Cell, vol. 13, no. 2, pp. 254-262, 2014.

[14] J. Hoffmann, J. Haendeler, A. Aicher et al., "Aging enhances the sensitivity of endothelial cells toward apoptotic stimuli: important role of nitric oxide," Circulation Research, vol. 89, no. 8, pp. 709-715, 2001.

[15] A. Csiszar, Z. Ungvari, J. G. Edwards et al., "Aging-induced phenotypic changes and oxidative stress impair coronary arteriolar function," Circulation Research, vol. 90, no. 11, pp. 1159-1166, 2002.

[16] M. R. Tschudi, M. Barton, N. A. Bersinger et al., "Effect of age on kinetics of nitric oxide release in rat aorta and pulmonary artery," The Journal of Clinical Investigation, vol. 98, no. 4, pp. 899-905, 1996.

[17] T. Tanabe, S. Maeda, T. Miyauchi et al., "Exercise training improves ageing-induced decrease in eNOS expression of the aorta," Acta Physiologica Scandinavica, vol. 178, no. 1, pp. 3-10, 2003.

[18] A. J. Donato, G. D. Henson, C. R. Hart et al., "The impact of ageing on adipose structure, function and vasculature in the B6D2F1 mouse: evidence of significant multisystem dysfunction," The Journal of Physiology, vol. 592, no. 18, pp. 4083-4096, 2014.

[19] J. R. Durrant, D. R. Seals, M. L. Connell et al., "Voluntary wheel running restores endothelial function in conduit arteries of old mice: direct evidence for reduced oxidative stress, increased superoxide dismutase activity and down-regulation of NADPH oxidase," The Journal of Physiology, vol. 587, no. 13, pp. 32713285, 2009.

[20] I. Eskurza, Z. D. Kahn, and D. R. Seals, "Xanthine oxidase does not contribute to impaired peripheral conduit artery endothelium-dependent dilatation with ageing," The Journal of Physiology, vol. 571, no. 3, pp. 661-668, 2006.

[21] C. A. Hamilton, M. J. Brosnan, M. McIntyre, D. Graham, and A. F. Dominiczak, "Superoxide excess in hypertension and aging: a common cause of endothelial dysfunction," Hypertension, vol. 37, no. 2, pp. 529-534, 2001.

[22] S. Chrissobolis and F. M. Faraci, "The role of oxidative stress and NADPH oxidase in cerebrovascular disease," Trends in Molecular Medicine, vol. 14, no. 11, pp. 495-502, 2008.

[23] W. G. Mayhan, D. M. Arrick, G. M. Sharpe, and H. Sun, "Agerelated alterations in reactivity of cerebral arterioles: role of oxidative stress," Microcirculation, vol. 15, no. 3, pp. 225-236, 2008.

[24] L. Park, J. Anrather, H. Girouard, P. Zhou, and C. Iadecola, "Nox2-derived reactive oxygen species mediate neurovascular dysregulation in the aging mouse brain," Journal of Cerebral Blood Flow and Metabolism, vol. 27, no. 12, pp. 1908-1918, 2007.

[25] B. van der Loo, R. Labugger, J. N. Skepper et al., "Enhanced peroxynitrite formation is associated with vascular aging," The
Journal of Experimental Medicine, vol. 192, no. 12, pp. 1731-1744, 2000.

[26] M. J. Luttrell, J. W. Seawright, E. Wilson, and C. R. Woodman, "Effect of age and exercise training on protein:protein interactions among eNOS and its regulatory proteins in rat aortas," European Journal of Applied Physiology, vol. 113, no. 11, pp. 27612768, 2013.

[27] C. Chen and D. B. Khismatullin, "Oxidized low-density lipoprotein contributes to atherogenesis via co-activation of macrophages and mast cells," PLoS ONE, vol. 10, no. 3, Article ID e0123088, 2015.

[28] K. Yang, X. J. Zhang, L. J. Cao et al., "Toll-like receptor 4 mediates inflammatory cytokine secretion in smooth muscle cells induced by oxidized low-density lipoprotein," PLOS ONE, vol. 9, no. 4, Article ID e95935, 2014.

[29] C. Meisinger, J. Baumert, N. Khuseyinova, H. Loewel, and W. Koenig, "Plasma oxidized low-density lipoprotein, a strong predictor for acute coronary heart disease events in apparently healthy, middle-aged men from the general population," Circulation, vol. 112, no. 5, pp. 651-657, 2005.

[30] M. Barton, F. Cosentino, R. P. Brandes, P. Moreau, S. Shaw, and T. F. Lüscher, "Anatomic heterogeneity of vascular aging: role of nitric oxide and endothelin," Hypertension, vol. 30, no. 4, pp. 817-824, 1997.

[31] F. Gündüz, Ü. K. Şentürk, O. Kuru, B. Aktekin, and M. R. Aktekin, "The effect of one year's swimming exercise on oxidant stress and antioxidant capacity in aged rats," Physiological Research, vol. 53, no. 2, pp. 171-176, 2004.

[32] I. Eskurza, K. D. Monahan, J. A. Robinson, and D. R. Seals, "Effect of acute and chronic ascorbic acid on flow-mediated dilatation with sedentary and physically active human ageing," The Journal of Physiology, vol. 556, no. 1, pp. 315-324, 2004.

[33] R. Tatchum-Talom and D. S. Martin, "Tempol improves vascular function in the mesenteric vascular bed of senescent rats," Canadian Journal of Physiology and Pharmacology, vol. 82, no. 3, pp. 200-207, 2004.

[34] A. A. Brown and F. B. Hu, "Dietary modulation of endothelial function: implications for cardiovascular disease," American Journal of Clinical Nutrition, vol. 73, no. 4, pp. 673-686, 2001.

[35] Y. Wang, C. Xu, Y. Liang, and P. M. Vanhoutte, "SIRT1 in metabolic syndrome: where to target matters," Pharmacology \& Therapeutics, vol. 136, no. 3, pp. 305-318, 2012.

[36] B. Bai, P. M. Vanhoutte, and Y. Wang, "Loss-of-SIRT1 function during vascular ageing: hyperphosphorylation mediated by cyclin-dependent kinase 5," Trends in Cardiovascular Medicine, vol. 24, no. 2, pp. 81-84, 2014.

[37] H.-Z. Chen, Y.-Z. Wan, and D.-P. Liu, "Cross-talk between SIRT1 and p66Shc in vascular diseases," Trends in Cardiovascular Medicine, vol. 23, no. 7, pp. 237-241, 2013.

[38] B. Bai, Y. Liang, C. Xu et al., "Cyclin-dependent kinase 5mediated hyperphosphorylation of sirtuin-1 contributes to the development of endothelial senescence and atherosclerosis," Circulation, vol. 126, no. 6, pp. 729-740, 2012.

[39] H. Ota, M. Akishita, M. Eto, K. Iijima, M. Kaneki, and Y. Ouchi, "Sirtl modulates premature senescence-like phenotype in human endothelial cells," Journal of Molecular and Cellular Cardiology, vol. 43, no. 5, pp. 571-579, 2007.

[40] A. J. Donato, K. A. Magerko, B. R. Lawson, J. R. Durrant, L. A. Lesniewski, and D. R. Seals, "SIRT-1 and vascular endothelial dysfunction with ageing in mice and humans," The Journal of Physiology, vol. 589, no. 18, pp. 4545-4554, 2011. 
[41] Y. Zu, L. Liu, M. Y. K. Lee et al., "SIRT1 promotes proliferation and prevents senescence through targeting LKB1 in primary porcine aortic endothelial cells," Circulation Research, vol. 106, no. 8, pp. 1384-1393, 2010.

[42] M. J. Zarzuelo, R. López-Sepúlveda, M. Sánchez et al., "SIRT1 inhibits NADPH oxidase activation and protects endothelial function in the rat aorta: Implications for vascular aging," Biochemical Pharmacology, vol. 85, no. 9, pp. 1288-1296, 2013.

[43] W. T. Nicholson, B. Vaa, C. Hesse, J. H. Eisenach, and M. J. Joyner, "Aging is associated with reduced prostacyclin-mediated dilation in the human forearm," Hypertension, vol. 53, no. 6, pp. 973-978, 2009.

[44] M. Nakajima, M. Hashimoto, F. Wang et al., "Aging decreases the production of $\mathrm{PGI}_{2}$ in rat aortic endothelial cells," Experimental Gerontology, vol. 32, no. 6, pp. 685-693, 1997.

[45] E. Gomez, C. Schwendemann, S. Roger et al., "Aging and prostacyclin responses in aorta and platelets from WKY and SHR rats," The American Journal of Physiology-Heart and Circulatory Physiology, vol. 295, no. 5, pp. H2198-H2211, 2008.

[46] J. N. Morris, J. A. Heady, P. A. B. Raffle, C. G. Roberts, and J. W. Parks, "Coronary heart-disease and physical activity of work," The Lancet, vol. 262, no. 6795, pp. 1053-1057, 1953.

[47] V. W. Barry, M. Baruth, M. W. Beets, J. L. Durstine, J. Liu, and S. N. Blair, "Fitness vs. fatness on all-cause mortality: a metaanalysis," Progress in Cardiovascular Diseases, vol. 56, no. 4, pp. 382-390, 2014.

[48] J. D. Berry, A. Pandey, A. Gao et al., "Physical fitness and risk for heart failure and coronary artery disease," Circulation: Heart Failure, vol. 6, no. 4, pp. 627-634, 2013.

[49] A. K. Chomistek, D. I. Chasman, N. R. Cook, E. B. Rimm, and I.-M. Lee, "Physical activity, genes for physical fitness, and risk of coronary heart disease," Medicine and Science in Sports \& Exercise, vol. 45, no. 4, pp. 691-697, 2013.

[50] D. J. Duncker, E. D. van Deel, M. C. de Waard, M. de Boer, D. Merkus, and J. van der Velden, "Exercise training in adverse cardiac remodeling," Pflugers Archiv European Journal of Physiology, vol. 466, no. 6, pp. 1079-1091, 2014.

[51] A. Holtermann, J. L. Marott, F. Gyntelberg et al., "Self-reported cardiorespiratory fitness: prediction and classification of risk of cardiovascular disease mortality and longevity-a prospective investigation in the Copenhagen City Heart Study," Journal of the American Heart Association, vol. 4, no. 1, 2014.

[52] M. J. Joyner and D. J. Green, "Exercise protects the cardiovascular system: effects beyond traditional risk factors," The Journal of Physiology, vol. 587, no. 23, pp. 5551-5558, 2009.

[53] S. Kurl, J. A. Laukkanen, R. Rauramaa, T. A. Lakka, J. Sivenius, and J. T. Salonen, "Cardiorespiratory fitness and the risk for stroke in men," Archives of Internal Medicine, vol. 163, no. 14, pp. 1682-1688, 2003.

[54] I.-M. Lee, E. J. Shiroma, F. Lobelo et al., "Effect of physical inactivity on major non-communicable diseases worldwide: an analysis of burden of disease and life expectancy," The Lancet, vol. 380, no. 9838, pp. 219-229, 2012.

[55] P. Schnohr, J. H. O'Keefe, J. L. Marott, P. Lange, and G. B. Jensen, "Dose of jogging and long-term mortality: the Copenhagen City Heart Study," Journal of the American College of Cardiology, vol. 65, no. 5, pp. 411-419, 2015.

[56] D. L. Swift, C. J. Lavie, N. M. Johannsen et al., "Physical activity, cardiorespiratory fitness, and exercise training in primary and secondary coronary prevention," Circulation Journal, vol. 77, no. 2, pp. 281-292, 2013.
[57] R. Vigen, C. Ayers, B. Willis, L. DeFina, and J. D. Berry, "Association of cardiorespiratory fitness with total, cardiovascular, and noncardiovascular mortality across 3 decades of follow-up in men and women," Circulation: Cardiovascular Quality and Outcomes, vol. 5, no. 3, pp. 358-364, 2012.

[58] M. A. West, D. Lythgoe, C. P. Barben et al., "Cardiopulmonary exercise variables are associated with postoperative morbidity after major colonic surgery: a prospective blinded observational study," British Journal of Anaesthesia, vol. 112, no. 4, pp. 665-671, 2014.

[59] J. Y. Chau, A. Grunseit, K. Midthjell et al., "Sedentary behaviour and risk of mortality from all-causes and cardiometabolic diseases in adults: evidence from the HUNT3 population cohort," British Journal of Sports Medicine, vol. 49, pp. 737-742, 2015.

[60] B. B. Gibbs, J. P. Reis, E. B. Schelbert et al., "Sedentary screen time and left ventricular structure and function: the CARDIA study," Medicine and Science in Sports \& Exercise, vol. 46, no. 2, pp. 276-283, 2014.

[61] M. T. Hamilton, D. G. Hamilton, and T. W. Zderic, "Role of low energy expenditure and sitting in obesity, metabolic syndrome, type 2 diabetes, and cardiovascular disease," Diabetes, vol. 56, no. 11, pp. 2655-2667, 2007.

[62] P. T. Katzmarzyk, T. S. Church, C. L. Craig, and C. Bouchard, "Sitting time and mortality from all causes, cardiovascular disease, and cancer," Medicine \& Science in Sports \& Exercise, vol. 41, no. 5, pp. 998-1005, 2009.

[63] U. Laufs, S. Wassmann, T. Czech et al., "Physical inactivity increases oxidative stress, endothelial dysfunction, and atherosclerosis," Arteriosclerosis, Thrombosis, and Vascular Biology, vol. 25, no. 4, pp. 809-814, 2005.

[64] A. E. Staiano, D. M. Harrington, T. V. Barreira, and P. T. Katzmarzyk, "Sitting time and cardiometabolic risk in US adults: associations by sex, race, socioeconomic status and activity level," British Journal of Sports Medicine, vol. 48, no. 3, pp. 213-219, 2014.

[65] E. Stamatakis, J. Y. Chau, Z. Pedisic et al., "Are sitting occupations associated with increased all-cause, cancer, and cardiovascular disease mortality risk? A pooled analysis of seven british population cohorts," PLoS ONE, vol. 8, no. 9, Article ID e73753, 2013.

[66] H. P. van der Ploeg, T. Chey, R. J. Korda, E. Banks, and A. Bauman, "Sitting time and all-cause mortality risk in 222497 Australian adults," Archives of Internal Medicine, vol. 172, no. 6, pp. 494-500, 2012.

[67] E. G. Wilmot, C. L. Edwardson, F. A. Achana et al., "Sedentary time in adults and the association with diabetes, cardiovascular disease and death: systematic review and meta-analysis," Diabetologia, vol. 55, no. 11, pp. 2895-2905, 2012.

[68] D. R. Young, K. Reynolds, M. Sidell et al., "Effects of physical activity and sedentary time on the risk of heart failure," Circulation: Heart Failure, vol. 7, no. 1, pp. 21-27, 2014.

[69] J. Szostak and P. Laurant, "The forgotten face of regular physical exercise: a 'natural' anti-atherogenic activity,' Clinical Science, vol. 121, no. 3, pp. 91-106, 2011.

[70] H. Miyazaki, S. Oh-ishi, T. Ookawara et al., "Strenuous endurance training in humans reduces oxidative stress following exhausting exercise," European Journal of Applied Physiology, vol. 84, no. 1-2, pp. 1-6, 2001.

[71] T. Fukai, M. R. Siegfried, M. Ushio-Fukai, Y. Cheng, G. Kojda, and D. G. Harrison, "Regulation of the vascular extracellular superoxide dismutase by nitric oxide and exercise training," 
Journal of Clinical Investigation, vol. 105, no. 11, pp. 631-1639, 2000.

[72] F. Moien-Afshari, S. Ghosh, M. Khazaei, T. J. Kieffer, R. W. Brownsey, and I. Laher, "Exercise restores endothelial function independently of weight loss or hyperglycaemic status in $\mathrm{db} / \mathrm{db}$ mice," Diabetologia, vol. 51, no. 7, pp. 1327-1337, 2008.

[73] A. W. Ashor, J. Lara, M. Siervo et al., "Exercise modalities and endothelial function: a systematic review and dose-response meta-analysis of randomized controlled trials," Sports Medicine, vol. 45, no. 2, pp. 279-296, 2014.

[74] G. K. Birk, E. A. Dawson, A. M. Batterham et al., "Effects of exercise intensity on flow mediated dilation in healthy humans," International Journal of Sports Medicine, vol. 34, no. 5, pp. 409414, 2013.

[75] F. Farsidfar, E. Kasikcioglu, H. Oflaz, D. Kasikcioglu, M. Meric, and S. Umman, "Effects of different intensities of acute exercise on flow-mediated dilatation in patients with coronary heart disease," International Journal of Cardiology, vol. 124, no. 3, pp. 372-374, 2008.

[76] C. Goto, Y. Higashi, M. Kimura et al., "Effect of different intensities of exercise on endothelium-dependent vasodilation in humans," Circulation, vol. 108, no. 5, pp. 530-535, 2003.

[77] T.-H. Luk, Y.-L. Dai, C.-W. Siu et al., "Effect of exercise training on vascular endothelial function in patients with stable coronary artery disease: a randomized controlled trial," European Journal of Preventive Cardiology, vol. 19, no. 4, pp. 830-839, 2012.

[78] W. Mitranun, C. Deerochanawong, H. Tanaka, and D. Suksom, "Continuous vs interval training on glycemic control and macro- and microvascular reactivity in type 2 diabetic patients," Scandinavian Journal of Medicine \& Science in Sports, vol. 24, no. 2, pp. e69-e76, 2014.

[79] J. M. Murias, K. N. Grise, M. Jiang, H. Kowalchuk, C. W. J. Melling, and E. G. Noble, "Acute endurance exercise induces changes in vasorelaxation responses that are vessel-specific," The American Journal of Physiology-Regulatory Integrative and Comparative Physiology, vol. 304, no. 7, pp. R574-R580, 2013.

[80] M. Rakobowchuk, S. Tanguay, K. A. Burgomaster, K. R. Howarth, M. J. Gibala, and M. J. MacDonald, "Sprint interval and traditional endurance training induce similar improvements in peripheral arterial stiffness and flow-mediated dilation in healthy humans," American Journal of PhysiologyRegulatory Integrative and Comparative Physiology, vol. 295, no. 1, pp. R236-R242, 2008.

[81] T. M. Tinken, D. H. J. Thijssen, N. Hopkins, E. A. Dawson, N. T. Cable, and D. J. Green, "Shear stress mediates endothelial adaptations to exercise training in humans," Hypertension, vol. 55, no. 2, pp. 312-318, 2010.

[82] S. S. Thosar, B. D. Johnson, J. D. Johnston, and J. P. Wallace, "Sitting and endothelial dysfunction: the role of shear stress," Medical Science Monitor, vol. 18, no. 12, pp. 173-180, 2012.

[83] S. S. Thosar, S. L. Bielko, K. J. Mather, J. D. Johnston, and J. P. Wallace, "Effect of prolonged sitting and breaks in sitting time on endothelial function," Medicine \& Science in Sports \& Exercise, vol. 47, no. 4, pp. 843-849, 2015.

[84] C. Demiot, F. Dignat-George, J.-O. Fortrat et al., "WISE 2005: chronic bed rest impairs microcirculatory endothelium in women," The American Journal of Physiology-Heart and Circulatory Physiology, vol. 293, no. 5, pp. H3159-H3164, 2007.

[85] G. K. Birk, E. A. Dawson, C. Atkinson et al., "Brachial artery adaptation to lower limb exercise training: role of shear stress," Journal of Applied Physiology, vol. 112, no. 10, pp. 1653-1658, 2012.
[86] S. Lee, Y. Park, K. C. Dellsperger, and C. Zhang, "Exercise training improves endothelial function via adiponectindependent and independent pathways in type 2 diabetic mice," The American Journal of Physiology-Heart and Circulatory Physiology, vol. 301, no. 2, pp. H306-H314, 2011.

[87] B. Hobson and J. Denekamp, "Endothelial proliferation in tumours and normal tissues: continuous labelling studies," British Journal of Cancer, vol. 49, no. 4, pp. 405-413, 1984.

[88] B. A. Caplan and C. J. Schwartz, "Increased endothelial cell turnover in areas of in vivo Evans Blue uptake in the pig aorta," Atherosclerosis, vol. 17, no. 3, pp. 401-417, 1973.

[89] C. M. Warboys, A. de Luca, N. Amini et al., "Disturbed flow promotes endothelial senescence via a p53-dependent pathway," Arteriosclerosis, Thrombosis, and Vascular Biology, vol. 34, no. 5, pp. 985-995, 2014.

[90] J. D. Erusalimsky, "Vascular endothelial senescence: from mechanisms to pathophysiology," Journal of Applied Physiology, vol. 106, no. 1, pp. 326-332, 2009.

[91] C. Blanpain and E. Fuchs, "Epidermal stem cells of the skin," Annual Review of Cell and Developmental Biology, vol. 22, pp. 339-373, 2006.

[92] X. Shi and D. J. Garry, "Muscle stem cells in development, regeneration, and disease," Genes \& Development, vol. 20, no. 13, pp. 1692-1708, 2006.

[93] T. Asahara, T. Murohara, A. Sullivan et al., "Isolation of putative progenitor endothelial cells for angiogenesis," Science, vol. 275, no. 5302, pp. 964-967, 1997.

[94] T. Asahara, H. Masuda, T. Takahashi et al., "Bone marrow origin of endothelial progenitor cells responsible for postnatal vasculogenesis in physiological and pathological neovascularization," Circulation Research, vol. 85, no. 3, pp. 221-228, 1999.

[95] M. Reyes, A. Dudek, B. Jahagirdar, L. Koodie, P. H. Marker, and C. M. Verfaillie, "Origin of endothelial progenitors in human postnatal bone marrow," The Journal of Clinical Investigation, vol. 109, no. 3, pp. 337-346, 2002.

[96] E. Zengin, F. Chalajour, U. M. Gehling et al., "Vascular wall resident progenitor cells: a source for postnatal vasculogenesis," Development, vol. 133, no. 8, pp. 1543-1551, 2006.

[97] W. H. Xia, Z. Yang, S. Y. Xu et al., "Age-related decline in reendothelialization capacity of human endothelial progenitor cells is restored by shear stress," Hypertension, vol. 59, no. 6, pp. 1225-1231, 2012.

[98] W.-H. Xia, J. Li, C. Su et al., "Physical exercise attenuates age-associated reduction in endothelium-reparative capacity of endothelial progenitor cells by increasing CXCR4/JAK-2 signaling in healthy men," Aging Cell, vol. 11, no. 1, pp. 111-119, 2012.

[99] J. Case, L. E. Mead, W. K. Bessler et al., "Human $\mathrm{CD} 34^{+} \mathrm{AC} 133^{+}$VEGFR-2 ${ }^{+}$cells are not endothelial progenitor cells but distinct, primitive hematopoietic progenitors," Experimental Hematology, vol. 35, no. 7, pp. 1109-1118, 2007.

[100] K. S. Cohen, S. Cheng, M. G. Larson et al., "Circulating CD $34^{+}$ progenitor cell frequency is associated with clinical and genetic factors," Blood, vol. 121, no. 8, pp. e50-e56, 2013.

[101] U. Ritz, V. Spies, I. Mehling, D. Gruszka, P. M. Rommens, and A. Hofmann, "Mobilization of CD $34^{+}$-progenitor cells in patients with severe trauma," PLoS ONE, vol. 9, no. 5, Article ID e97369, 2014.

[102] R. S. Patel, Q. Li, N. Ghasemzadeh et al., "Circulating CD $34^{+}$ progenitor cells and risk of mortality in a population with coronary artery disease," Circulation Research, vol. 116, no. 2, pp. 289-297, 2015. 
[103] C. Heiss, S. Keymel, U. Niesler, J. Ziemann, M. Kelm, and C. Kalka, "Impaired progenitor cell activity in age-related endothelial dysfunction," Journal of the American College of Cardiology, vol. 45, no. 9, pp. 1441-1448, 2005.

[104] D. H. J. Thijssen, J. B. Vos, C. Verseyden et al., "Haematopoietic stem cells and endothelial progenitor cells in healthy men: effect of aging and training," Aging Cell, vol. 5, no. 6, pp. 495-503, 2006.

[105] G. L. Hoetzer, G. P. Van Guilder, H. M. Irmiger, R. S. Keith, B. L. Stauffer, and C. A. DeSouza, "Aging, exercise, and endothelial progenitor cell clonogenic and migratory capacity in men," Journal of Applied Physiology, vol. 102, no. 3, pp. 847-852, 2007.

[106] T. Thum, S. Hoeber, S. Froese et al., "Age-dependent impairment of endothelial progenitor cells is corrected by growth hormone mediated increase of insulin-like growth factor-1," Circulation Research, vol. 100, no. 3, pp. 434-443, 2007.

[107] E. J. Kushner, G. P. Van Guilder, O. J. MacEneaney, J. N. Cech, B. L. Stauffer, and C. A. DeSouza, "Aging and endothelial progenitor cell telomere length in healthy men," Clinical Chemistry and Laboratory Medicine, vol. 47, no. 1, pp. 47-50, 2009.

[108] E. Kushner, G. Van Guilder, O. MacEneaney et al., "Ageing and endothelial progenitor cell release of proangiogenic cytokines," Age and Ageing, vol. 39, no. 2, Article ID afp244, pp. 268-272, 2010.

[109] K. A. Williamson, A. Hamilton, J. A. Reynolds et al., "Agerelated impairment of endothelial progenitor cell migration correlates with structural alterations of heparan sulfate proteoglycans," Aging Cell, vol. 12, no. 1, pp. 139-147, 2013.

[110] Z. Yang, W.-H. Xia, C. Su et al., "Regular exercise-induced increased number and activity of circulating endothelial progenitor cells attenuates age-related decline in arterial elasticity in healthy men," International Journal of Cardiology, vol. 165, no. 2, pp. 247-254, 2013.

[111] G. Pasquinelli, P. L. Tazzari, C. Vaselli et al., "Thoracic aortas from multiorgan donors are suitable for obtaining resident angiogenic mesenchymal stromal cells," Stem Cells, vol. 25, no. 7, pp. 1627-1634, 2007.

[112] J. N. Passman, X. R. Dong, S.-P. Wu et al., "A sonic hedgehog signaling domain in the arterial adventitia supports resident $\mathrm{Scal}^{+}$smooth muscle progenitor cells," Proceedings of the National Academy of Sciences of the United States of America, vol. 105, no. 27, pp. 9349-9354, 2008.

[113] J. Hur, C.-H. Yoon, H.-S. Kim et al., "Characterization of two types of endothelial progenitor cells and their different contributions to neovasculogenesis," Arteriosclerosis, Thrombosis, and Vascular Biology, vol. 24, no. 2, pp. 288-293, 2004.

[114] M. C. Barsotti, T. Santoni, M. E. L. Picoi et al., "Endothelial progenitor cell homing in human myocardium in patients with coronary artery disease," International Journal of Cardiology, vol. 172, no. 2, pp. 516-517, 2014.

[115] A. E. Berezin and A. A. Kremzer, "Circulating endothelial progenitor cells as markers for severity of ischemic chronic heart failure," Journal of Cardiac Failure, vol. 20, no. 6, pp. 438447, 2014.

[116] L. Bruyndonckx, V. Y. Hoymans, G. Frederix et al., "Endothelial progenitor cells and endothelial microparticles are independent predictors of endothelial function," The Journal of Pediatrics, vol. 165, no. 2, pp. 300-305, 2014.

[117] R. Castejon, C. Jimenez-Ortiz, S. Valero-Gonzalez, S. Rosado, S. Mellor, and M. Yebra-Bango, "Decreased circulating endothelial progenitor cells as an early risk factor of subclinical atherosclerosis in systemic lupus erythematosus," Rheumatology, vol. 53, no. 4, pp. 631-638, 2014.

[118] K. H. Chan, P. J. L. Simpson, A. S. Yong et al., “The relationship between endothelial progenitor cell populations and epicardial and microvascular coronary disease-a cellular, angiographic and physiologic study," PLOS ONE, vol. 9, no. 4, Article ID e93980, 2014.

[119] G. P. Fadini, A. Coracina, I. Baesso et al., "Peripheral blood $\mathrm{CD} 34^{+} \mathrm{KDR}^{+}$endothelial progenitor cells are determinants of subclinical atherosclerosis in a middle-aged general population," Stroke, vol. 37, no. 9, pp. 2277-2282, 2006.

[120] G. P. Fadini, M. Miorin, M. Facco et al., "Circulating endothelial progenitor cells are reduced in peripheral vascular complications of type 2 diabetes mellitus," Journal of the American College of Cardiology, vol. 45, no. 9, pp. 1449-1457, 2005.

[121] J. M. Hill, G. Zalos, J. P. J. Halcox et al., "Circulating endothelial progenitor cells, vascular function, and cardiovascular risk," The New England Journal of Medicine, vol. 348, no. 7, pp. 593-600, 2003.

[122] C. Jung, A. Rafnsson, A. Shemyakin, F. Böhm, and J. Pernow, "Different subpopulations of endothelial progenitor cells and circulating apoptotic progenitor cells in patients with vascular disease and diabetes," International Journal of Cardiology, vol. 143, no. 3, pp. 368-372, 2010.

[123] S. A. Kocaman, M. R. Yalçın, M. Yağcı et al., "Endothelial progenitor cells (CD34+KDR+) and monocytes may provide the development of good coronary collaterals despite the vascular risk factors and extensive atherosclerosis," Anadolu Kardiyoloji Dergisi, vol. 11, no. 4, pp. 290-299, 2011.

[124] Y.-F. Liao, Y. Feng, L.-L. Chen, T.-S. Zeng, F. Yu, and L.J. $\mathrm{Hu}$, "Coronary heart disease risk equivalence in diabetes and arterial diseases characterized by endothelial function and endothelial progenitor cell," Journal of Diabetes and its Complications, vol. 28, no. 2, pp. 214-218, 2014.

[125] X. Liu and C. Xie, "Human endothelial progenitor cells isolated from COPD patients are dysfunctional," Molecular and Cellular Biochemistry, vol. 363, no. 1-2, pp. 53-63, 2012.

[126] A. Massot, M. Navarro-Sobrino, A. Penalba et al., "Decreased levels of angiogenic growth factors in intracranial atherosclerotic disease despite severity-related increase in endothelial progenitor cell counts," Cerebrovascular Diseases, vol. 35, no. 1, pp. 81-88, 2013.

[127] T. M. Powell, J. D. Paul, J. M. Hill et al., "Granulocyte colonystimulating factor mobilizes functional endothelial progenitor cells in patients with coronary artery disease," Arteriosclerosis, Thrombosis, and Vascular Biology, vol. 25, no. 2, pp. 296-301, 2005.

[128] R. P. W. Rouhl, A. E. C. S. Mertens, R. J. van Oostenbrugge et al., "Angiogenic T-cells and putative endothelial progenitor cells in hypertension-related cerebral small vessel disease," Stroke, vol. 43, no. 1, pp. 256-258, 2012.

[129] C. Schmidt-Lucke, L. Rössig, S. Fichtlscherer et al., "Reduced number of circulating endothelial progenitor cells predicts future cardiovascular events: proof of concept for the clinical importance of endogenous vascular repair," Circulation, vol. 111, no. 22, pp. 2981-2987, 2005.

[130] E. Shantsila, B. J. Wrigley, A. Shantsila, L. D. Tapp, P. S. Gill, and G. Y. H. Lip, "Monocyte-derived and $\mathrm{CD} 34^{+} / \mathrm{KDR}^{+}$endothelial progenitor cells in heart failure," Journal of Thrombosis and Haemostasis, vol. 10, no. 7, pp. 1252-1261, 2012. 
[131] L. Sibal, A. Aldibbiat, S. C. Agarwal et al., "Circulating endothelial progenitor cells, endothelial function, carotid intima-media thickness and circulating markers of endothelial dysfunction in people with type 1 diabetes without macrovascular disease or microalbuminuria," Diabetologia, vol. 52, no. 8, pp. 1464-1473, 2009.

[132] M. Teraa, R. W. Sprengers, P. E. Westerweel et al., "Bone marrow alterations and lower endothelial progenitor cell numbers in critical limb ischemia patients," PLoS ONE, vol. 8, no. 1, Article ID e55592, 2013.

[133] R. G. Turan, M. Brehm, M. Köstering et al., "Effects of exercise training on mobilization of BM-CPCs and migratory capacity as well as LVEF after AMI," Medizinische Klinik, vol. 101, pp. 198201, 2006.

[134] E. M. Van Craenenbroeck, P. J. Beckers, N. M. Possemiers et al., "Exercise acutely reverses dysfunction of circulating angiogenic cells in chronic heart failure," European Heart Journal, vol. 31, no. 15, pp. 1924-1934, 2010.

[135] M. Vasa, S. Fichtlscherer, A. Aicher et al., "Number and migratory activity of circulating endothelial progenitor cells inversely correlate with risk factors for coronary artery disease," Circulation Research, vol. 89, no. 1, pp. el-e7, 2001.

[136] K. Vemparala, A. Roy, V. K. Bahl et al., "Early accelerated senescence of circulating endothelial progenitor cells in premature coronary artery disease patients in a developing countrya case control study," BMC Cardiovascular Disorders, vol. 13, article 104, 2013.

[137] D. H. Walter, J. Haendeler, J. Reinhold et al., "Impaired CXCR4 signaling contributes to the reduced neovascularization capacity of endothelial progenitor cells from patients with coronary artery disease," Circulation Research, vol. 97, no. 11, pp. 1142-1151, 2005.

[138] Q. Xiao, S. Kiechi, S. Patel et al., "Endothelial progenitor cells, cardiovascular risk factors, cytokine levels and atherosclerosis-results from a large population-based study," PLoS ONE, vol. 2, no. 10, article e975, 2007.

[139] A. C. Alba, S. D. Lalonde, V. Rao, S. D. Walter, G. H. Guyatt, and H. J. Ross, "Changes in circulating progenitor cells are associated with outcome in heart failure patients: a longitudinal study," Canadian Journal of Cardiology, vol. 29, no. 12, pp. 16571664, 2013.

[140] F. Pelliccia, V. Pasceri, G. Rosano et al., "Endothelial progenitor cells predict long-term prognosis in patients with stable angina treated with percutaneous coronary intervention: five-year follow-up of the PROCREATION Study," Circulation Journal, vol. 77, no. 7, pp. 1728-1735, 2013.

[141] Y. Zhang, D. A. Ingram, M. P. Murphy et al., "Release of proinflammatory mediators and expression of proinflammatory adhesion molecules by endothelial progenitor cells," American Journal of Physiology-Heart and Circulatory Physiology, vol. 296, no. 5, pp. H1675-H1682, 2009.

[142] T. Padró, M. Steins, C.-X. Li et al., "Comparative analysis of plasminogen activator inhibitor-1 expression in different types of atherosclerotic lesions in coronary arteries from human heart explants," Cardiovascular Research, vol. 36, no. 1, pp. 28-36, 1997.

[143] R. E. Gerszten, E. A. Garcia-Zepeda, Y.-C. Lim et al., "MCP1 and IL-8 trigger firm adhesion of monocytes to vascular endothelium under flow conditions," Nature, vol. 398, no. 6729, pp. 718-725, 1999.

[144] D. Tousoulis, A. Briasoulis, G. Vogiatzi et al., "Effects of direct infusion of bone marrow-derived progenitor cells and indirect mobilization of hematopoietic progenitor cells on atherosclerotic plaque and inflammatory process in atherosclerosis," International Journal of Cardiology, vol. 168, no. 5, pp. 47694774, 2013.

[145] L. Yao, J. Heuser-Baker, O. Herlea-Pana et al., "Bone marrow endothelial progenitors augment atherosclerotic plaque regression in a mouse model of plasma lipid lowering," Stem Cells, vol. 30, no. 12, pp. 2720-2731, 2012.

[146] K. Tashiro, A. Nonaka, N. Hirata, T. Yamaguchi, H. Mizuguchi, and K. Kawabata, "Plasma elevation of vascular endothelial growth factor leads to the reduction of mouse hematopoietic and mesenchymal stem/progenitor cells in the bone marrow," Stem Cells and Development, vol. 23, no. 18, pp. 2202-2210, 2014.

[147] P.-H. Huang, Y.-H. Chen, C.-H. Wang et al., "Matrix metalloproteinase-9 is essential for ischemia-induced neovascularization by modulating bone marrow-derived endothelial progenitor cells," Arteriosclerosis, Thrombosis, and Vascular Biology, vol. 29, no. 8, pp. 1179-1184, 2009.

[148] K. Jujo, H. Hamada, A. Iwakura et al., "CXCR4 blockade augments bone marrow progenitor cell recruitment to the neovasculature and reduces mortality after myocardial infarction," Proceedings of the National Academy of Sciences of the United States of America, vol. 107, no. 24, pp. 11008-11013, 2010.

[149] L. Ling, Y. Shen, K. Wang et al., "Worse clinical outcomes in acute myocardial infarction patients with type 2 diabetes mellitus: relevance to impaired endothelial progenitor cells mobilization," PLoS ONE, vol. 7, no. 11, Article ID e50739, 2012.

[150] F. Jin, Q. Zhai, L. Qiu et al., "Degradation of BM SDF-1 by MMP9: the role in G-CSF-induced hematopoietic stem/progenitor cell mobilization," Bone Marrow Transplantation, vol. 42, no. 9, pp. 581-588, 2008.

[151] S. Hamed, B. Brenner, A. Aharon, D. Daoud, and A. Roguin, "Nitric oxide and superoxide dismutase modulate endothelial progenitor cell function in type 2 diabetes mellitus," Cardiovascular Diabetology, vol. 8, no. 1, article 56, 2009.

[152] C. Jiraritthamrong, P. Kheolamai, Y. U-Pratya et al., "In vitro vessel-forming capacity of endothelial progenitor cells in high glucose conditions," Annals of Hematology, vol. 91, no. 3, pp. 311320, 2012.

[153] M. F. Lombardo, P. Iacopino, M. Cuzzola et al., “Type 2 diabetes mellitus impairs the maturation of endothelial progenitor cells and increases the number of circulating endothelial cells in peripheral blood," Cytometry Part A, vol. 81, no. 10, pp. 856-864, 2012.

[154] S. Meng, J. Cao, X. Zhang et al., "Downregulation of microRNA130 a contributes to endothelial progenitor cell dysfunction in diabetic patients via its target Runx3," PLoS ONE, vol. 8, no. 7, Article ID e68611, 2013.

[155] G. Spinetti, D. Cordella, O. Fortunato et al., "Global remodeling of the vascular stem cell niche in bone marrow of diabetic patients: implication of the microRNA-155/FOXO3a signaling pathway," Circulation Research, vol. 112, no. 3, pp. 510-522, 2013.

[156] W.-S. Yue, K.-K. Lau, C.-W. Siu et al., "Impact of glycemic control on circulating endothelial progenitor cells and arterial stiffness in patients with type 2 diabetes mellitus," Cardiovascular Diabetology, vol. 10, no. 1, article 113, 2011.

[157] A. G. Gunin, V. V. Petrov, N. N. Golubtzova, O. V. Vasilieva, and N. K. Kornilova, "Age-related changes in angiogenesis in human dermis," Experimental Gerontology, vol. 55, no. 1, pp. 143-151, 2014. 
[158] M. J. Reed and J. M. Edelberg, "Impaired angiogenesis in the aged," Science of Aging Knowledge Environment, vol. 2004, no. 7, article pe7, 2004.

[159] A. Rivard, J.-E. Fabre, M. Silver et al., "Age-dependent impairment of angiogenesis," Circulation, vol. 99, no. 1, pp. 111-120, 1999.

[160] E. Sadoun and M. J. Reed, "Impaired angiogenesis in aging is associated with alterations in vessel density, matrix composition, inflammatory response, and growth factor expression," Journal of Histochemistry \& Cytochemistry, vol. 51, no. 9, pp. 1119-1130, 2003.

[161] J. Wang, X. Peng, R. M. Lassance-Soares et al., "Aging-induced collateral dysfunction: Impaired responsiveness of collaterals and susceptibility to apoptosis via dysfunctional eNOS signaling," Journal of Cardiovascular Translational Research, vol. 4, no. 6, pp. 779-789, 2011.

[162] I. B. Ø. Østhus, A. Sgura, F. Berardinelli et al., “Telomere length and long-term endurance exercise: does exercise training affect biological age? A pilot study," PLoS ONE, vol. 7, no. 12, Article ID e52769, 2012.

[163] E. Chang and C. B. Harley, "Telomere length and replicative aging in human vascular tissues," Proceedings of the National Academy of Sciences of the United States of America, vol. 92, no. 24, pp. 11190-11194, 1995.

[164] D. Jurk, C. Wilson, J. F. Passos et al., "Chronic inflammation induces telomere dysfunction and accelerates ageing in mice," Nature Communications, vol. 2, article 4172, 2014.

[165] G. Mandraffino, M. A. Sardo, S. Riggio et al., "Circulating progenitor cells and the elderly: a seven-year observational study," Experimental Gerontology, vol. 47, no. 5, pp. 394-400, 2012.

[166] Y. Wang, Q. Cao, F. Wang et al., "SIRT1 protects against oxidative stress-induced endothelial progenitor cells apoptosis by inhibiting FOXO3a via FOXO3a ubiquitination and degradation," Journal of Cellular Physiology, vol. 230, no. 9, pp. 2098-2107, 2015.

[167] P. Rimmelé, C. L. Bigarella, R. Liang et al., "Aging-like phenotype and defective lineage specification in SIRT1-deleted hematopoietic stem and progenitor cells," Stem Cell Reports, vol. 3, no. 1, pp. 44-59, 2014.

[168] W. B. Kannel and T. Gordon, "Evaluation of cardiovascular risk in the elderly: the Framingham study," Bulletin of the New York Academy of Medicine, vol. 54, no. 6, pp. 573-591, 1978.

[169] J. Zhou, M. Cheng, Y.-H. Liao et al., "Rosuvastatin enhances angiogenesis via eNOS-dependent mobilization of endothelial progenitor cells," PLoS ONE, vol. 8, no. 5, Article ID e63126, 2013.

[170] H. Ye, F. He, X. Fei et al., "High-dose atorvastatin reloading before percutaneous coronary intervention increased circulating endothelial progenitor cells and reduced inflammatory cytokine expression during the perioperative period," Journal of Cardiovascular Pharmacology and Therapeutics, vol. 19, no. 3, pp. 290-295, 2014.

[171] D. H. Walter, K. Rittig, F. H. Bahlmann et al., "Statin therapy accelerates reendothelialization: a novel effect involving mobilization and incorporation of bone marrow-derived endothelial progenitor cells," Circulation, vol. 105, no. 25, pp. 3017-3024, 2002.

[172] I. Spyridopoulos, J. Haendeler, C. Urbich et al., "Statins enhance migratory capacity by upregulation of the telomere repeatbinding factor TRF2 in endothelial progenitor cells," Circulation, vol. 110, no. 19, pp. 3136-3142, 2004.
[173] H. Shao, Y. Tan, D. Eton et al., "Statin and stromal cell-derived factor-1 additively promote angiogenesis by enhancement of progenitor cells incorporation into new vessels," Stem Cells, vol. 26, no. 5, pp. 1376-1384, 2008.

[174] E. Oikonomou, G. Siasos, M. Zaromitidou et al., "Atorvastatin treatment improves endothelial function through endothelial progenitor cells mobilization in ischemic heart failure patients," Atherosclerosis, vol. 238, no. 2, pp. 159-164, 2015.

[175] H.-F. Liu, X.-W. Qi, L.-L. Ma, D.-K. Yao, and L. Wang, "Atorvastatin improves endothelial progenitor cell function and reduces pulmonary hypertension in patients with chronic pulmonary heart disease," Experimental and Clinical Cardiology, vol. 18, no. 1, pp. e40-e43, 2013.

[176] U. Landmesser, N. Engberding, F. H. Bahlmann et al., "Statininduced improvement of endothelial progenitor cell mobilization, myocardial neovascularization, left ventricular function, and survival after experimental myocardial infarction requires endothelial nitric oxide synthase," Circulation, vol. 110, no. 14, pp. 1933-1939, 2004.

[177] M. A. Mughal, I. A. Alvi, I. A. Akhund, and A. K. Ansari, "The effects of aerobic exercise training on resting blood pressure in hypertensive patients," Journal of the Pakistan Medical Association, vol. 51, no. 6, pp. 222-226, 2001.

[178] S. A. M. Liu, J. Goodman, R. Nolan, S. Lacombe, and S. G. Thomas, "Blood pressure responses to acute and chronic exercise are related in prehypertension," Medicine \& Science in Sports \& Exercise, vol. 44, no. 9, pp. 1644-1652, 2012.

[179] A. Oberman, G. F. Fletcher, J. Lee et al., "Efficacy of highintensity exercise training on left ventricular ejection fraction in men with coronary artery disease (The Training Level Comparison Study)," The American Journal of Cardiology, vol. 76, no. 10, pp. 643-647, 1995.

[180] N. Mathur and B. K. Pedersen, "Exercise as a mean to control low-grade systemic inflammation," Mediators of Inflammation, vol. 2008, Article ID 109502, 6 pages, 2008.

[181] B. Hoier and Y. Hellsten, "Exercise-induced capillary growth in human skeletal muscle and the dynamics of VEGF," Microcirculation, vol. 21, no. 4, pp. 301-314, 2014.

[182] J. B. Gillen, J. P. Little, Z. Punthakee, M. A. Tarnopolsky, M. C. Riddell, and M. J. Gibala, "Acute high-intensity interval exercise reduces the postprandial glucose response and prevalence of hyperglycaemia in patients with type 2 diabetes," Diabetes, Obesity and Metabolism, vol. 14, no. 6, pp. 575-577, 2012.

[183] J. A. Babraj, N. B. J. Vollaard, C. Keast, F. M. Guppy, G. Cottrell, and J. A. Timmons, "Extremely short duration high intensity interval training substantially improves insulin action in young healthy males," BMC Endocrine Disorders, vol. 9, no. 1, article 3, 2009.

[184] V. Adams, K. Lenk, A. Linke et al., "Increase of circulating endothelial progenitor cells in patients with coronary artery disease after exercise-induced ischemia," Arteriosclerosis, Thrombosis, and Vascular Biology, vol. 24, no. 4, pp. 684-690, 2004.

[185] A. Aoki, M. Murata, T. Asano et al., "Prompt increases in retinol-binding protein 4 and endothelial progenitor cells during acute exercise load in diabetic subjects," Endocrine Journal, vol. 59, no. 12, pp. 1085-1091, 2012.

[186] M. R. Bonsignore, G. Morici, R. Riccioni et al., "Hemopoietic and angiogenetic progenitors in healthy athletes: different responses to endurance and maximal exercise," Journal of Applied Physiology, vol. 109, no. 1, pp. 60-67, 2010. 
[187] E. Chang, J. Paterno, D. Duscher et al., "Exercise induces stromal cell-derived factor- $1 \alpha$-mediated release of endothelial progenitor cells with increased vasculogenic function," Plastic and Reconstructive Surgery, vol. 135, no. 2, pp. 340e-350e, 2015.

[188] E. Goussetis, A. Spiropoulos, M. Tsironi et al., "Spartathlon, a 246 kilometer foot race: effects of acute inflammation induced by prolonged exercise on circulating progenitor reparative cells," Blood Cells, Molecules, and Diseases, vol. 42, no. 3, pp. 294-299, 2009.

[189] N. T. Jenkins, S. Witkowski, E. E. Spangenburg, and J. M. Hagberg, "Effects of acute and chronic endurance exercise on intracellular nitric oxide in putative endothelial progenitor cells: role of NAPDH oxidase," The American Journal of PhysiologyHeart and Circulatory Physiology, vol. 297, no. 5, pp. H1798H1805, 2009.

[190] U. Laufs, A. Urhausen, N. Werner et al., "Running exercise of different duration and intensity: effect on endothelial progenitor cells in healthy subjects," European Journal of Cardiovascular Prevention and Rehabilitation, vol. 12, no. 4, pp. 407-414, 2005.

[191] S. Möbius-Winkler, T. Hilberg, K. Menzel et al., "Timedependent mobilization of circulating progenitor cells during strenuous exercise in healthy individuals," Journal of Applied Physiology, vol. 107, no. 6, pp. 1943-1950, 2009.

[192] J. Rehman, J. Li, L. Parvathaneni et al., "Exercise acutely increases circulating endothelial progenitor cells and monocyte-/macrophage-derived angiogenic cells," Journal of the American College of Cardiology, vol. 43, no. 12, pp. 2314-2318, 2004.

[193] M. D. Ross, A. L. Wekesa, J. P. Phelan, and M. Harrison, "Resistance exercise increases endothelial progenitor cells and angiogenic factors," Medicine and Science in Sports \& Exercise, vol. 46, no. 1, pp. 16-23, 2014.

[194] M. Sandri, E. B. Beck, V. Adams et al., "Maximal exercise, limb ischemia, and endothelial progenitor cells," European Journal of Cardiovascular Prevention es Rehabilitation, vol. 18, no. 1, pp. 5564, 2011.

[195] M. Sandri, V. Adams, S. Gielen et al., "Effects of exercise and ischemia on mobilization and functional activation of bloodderived progenitor cells in patients with ischemic syndromes," Circulation, vol. 111, no. 25, pp. 3391-3399, 2005.

[196] G. Scalone, A. De Caterina, A. M. Leone et al., "Effect of exercise on circulating endothelial progenitor cells in microvascular angina," Circulation Journal, vol. 77, no. 7, pp. 1777-1782, 2013.

[197] R. Schier, R. El-Zein, A. Cortes et al., "Endothelial progenitor cell mobilization by preoperative exercise: a bone marrow response associated with postoperative outcome," British Journal of Anaesthesia, vol. 113, no. 4, pp. 652-660, 2014.

[198] R. G. Shaffer, S. Greene, A. Arshi et al., "Effect of acute exercise on endothelial progenitor cells in patients with peripheral arterial disease," Vascular Medicine, vol. 11, no. 4, pp. 219-226, 2006.

[199] E. M. Van Craenenbroeck, C. J. Vrints, S. E. Haine et al., "A maximal exercise bout increases the number of circulating $\mathrm{CD} 34+/ \mathrm{KDR}+$ endothelial progenitor cells in healthy subjects. Relation with lipid profile," Journal of Applied Physiology, vol. 104, no. 4, pp. 1006-1013, 2008.

[200] E. M. Van Craenenbroeck, L. Bruyndonckx, C. Van Berckelaer, V. Y. Hoymans, C. J. Vrints, and V. M. Conraads, "The effect of acute exercise on endothelial progenitor cells is attenuated in chronic heart failure," European Journal of Applied Physiology, vol. 111, no. 9, pp. 2375-2379, 2011.
[201] J.-S. Wang, M.-Y. Lee, H.-Y. Lien, and T.-P. Weng, "Hypoxic exercise training improves cardiac/muscular hemodynamics and is associated with modulated circulating progenitor cells in sedentary men," International Journal of Cardiology, vol. 170, no. 3, pp. 315-323, 2014.

[202] Z. Yang, J.-M. Wang, L. Chen, C.-F. Luo, A.-L. Tang, and J. Tao, "Acute exercise-induced nitric oxide production contributes to upregulation of circulating endothelial progenitor cells in healthy subjects," Journal of Human Hypertension, vol. 21, no. 6, pp. 452-460, 2007.

[203] J. L. Rummens, A. Daniëls, P. Dendale et al., "Suppressed increase in blood endothelial progenitor cell content as a result of single exhaustive exercise bout in male revascularised coronary artery disease patients," Acta Clinica Belgica, vol. 67, no. 4, pp. 262-269, 2012.

[204] V. Adams, A. Linke, F. Breuckmann et al., "Circulating progenitor cells decrease immediately after marathon race in advancedage marathon runners," European Journal of Cardiovascular Prevention \& Rehabilitation, vol. 15, no. 5, pp. 602-607, 2008.

[205] M. Okutsu, K. Ishii, K. J. Niu, and R. Nagatomi, "Cortisolinduced CXCR4 augmentation mobilizes T lymphocytes after acute physical stress," The American Journal of PhysiologyRegulatory Integrative and Comparative Physiology, vol. 288, no. 3, pp. R591-R599, 2005.

[206] O. A. Ajijola, C. Dong, E. E. Herderick, Q. Ma, P. J. Goldschmidt-Clermont, and Z. Yan, "Voluntary running suppresses proinflammatory cytokines and bone marrow endothelial progenitor cell levels in apolipoprotein-E-deficient mice," Antioxidants \& Redox Signaling, vol. 11, no. 1, pp. 15-23, 2009.

[207] F. Cesari, R. Marcucci, A. M. Gori et al., "Impact of a cardiac rehabilitation program and inflammatory state on endothelial progenitor cells in acute coronary syndrome patients," International Journal of Cardiology, vol. 167, no. 5, pp. 1854-1859, 2013.

[208] F. Cesari, F. Sofi, R. Caporale et al., "Relationship between exercise capacity, endothelial progenitor cells and cytochemokines in patients undergoing cardiac rehabilitation," Thrombosis and Haemostasis, vol. 101, no. 3, pp. 521-526, 2009.

[209] J. K. Choi, K. M. Moon, S. Y. Jung et al., "Regular exercise training increases the number of endothelial progenitor cells and decreases homocysteine levels in healthy peripheral blood," Korean Journal of Physiology and Pharmacology, vol. 18, no. 2, pp. 163-168, 2014.

[210] T. Fernandes, J. S. Nakamuta, F. C. Magalhães et al., "Exercise training restores the endothelial progenitor cells number and function in hypertension: implications for angiogenesis," Journal of Hypertension, vol. 30, no. 11, pp. 2133-2143, 2012.

[211] J. M. Fernández, D. Rosado-Álvarez, M. E. Da Silva Grigoletto et al., "Moderate-to-high-intensity training and a hypocaloric Mediterranean diet enhance endothelial progenitor cells and fitness in subjects with the metabolic syndrome," Clinical Science, vol. 123, no. 6, pp. 361-373, 2012.

[212] C. Fiorito, M. L. Balestrieri, E. Crimi et al., "Effect of l-arginine on circulating endothelial progenitor cells and VEGF after moderate physical training in mice," International Journal of Cardiology, vol. 126, no. 3, pp. 421-423, 2008.

[213] L. Gatta, A. Armani, F. Iellamo et al., "Effects of a shortterm exercise training on serum factors involved in ventricular remodelling in chronic heart failure patients," International Journal of Cardiology, vol. 155, no. 3, pp. 409-413, 2012.

[214] U. Laufs, N. Werner, A. Link et al., "Physical training increases endothelial progenitor cells, inhibits neointima formation, and 
enhances angiogenesis," Circulation, vol. 109, no. 2, pp. 220-226, 2004.

[215] F. Manfredini, G. M. Rigolin, A. M. Malagoni et al., "Exercise training and endothelial progenitor cells in haemodialysis patients," Journal of International Medical Research, vol. 37, no. 2, pp. 534-540, 2009.

[216] P. Sarto, E. Balducci, G. Balconi et al., "Effects of exercise training on endothelial progenitor cells in patients with chronic heart failure," Journal of Cardiac Failure, vol. 13, no. 9, pp. 701708, 2007.

[217] O. Schlager, A. Giurgea, O. Schuhfried et al., "Exercise training increases endothelial progenitor cells and decreases asymmetric dimethylarginine in peripheral arterial disease: a randomized controlled trial," Atherosclerosis, vol. 217, no. 1, pp. 240-248, 2011.

[218] K. Sonnenschein, T. Horváth, M. Mueller et al., "Exercise training improves in vivo endothelial repair capacity of early endothelial progenitor cells in subjects with metabolic syndrome," European Journal of Cardiovascular Prevention \& Rehabilitation, vol. 18, no. 3, pp. 406-414, 2011.

[219] S. Steiner, A. Niessner, S. Ziegler et al., "Endurance training increases the number of endothelial progenitor cells in patients with cardiovascular risk and coronary artery disease," Atherosclerosis, vol. 181, no. 2, pp. 305-310, 2005.

[220] E. M. Van Craenenbroeck, V. Y. Hoymans, P. J. Beckers et al., "Exercise training improves function of circulating angiogenic cells in patients with chronic heart failure," Basic Research in Cardiology, vol. 105, no. 5, pp. 665-676, 2010.

[221] J. Zhang, X. Zhang, H. Li et al., "Hyperglycaemia exerts deleterious effects on late endothelial progenitor cell secretion actions," Diabetes and Vascular Disease Research, vol. 10, no. 1, pp. 49-56, 2013.

[222] S. Witkowski, M. M. Lockard, N. T. Jenkins, T. O. Obisesan, E. E. Spangenburg, and J. M. Hagberg, "Relationship between circulating progenitor cells, vascular function and oxidative stress with long-term training and short-term detraining in older men," Clinical Science, vol. 118, no. 4, pp. 303-311, 2010. 


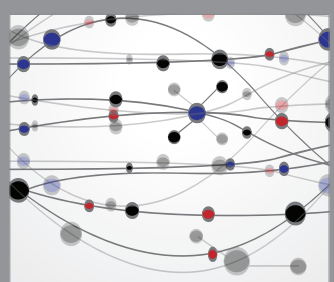

The Scientific World Journal
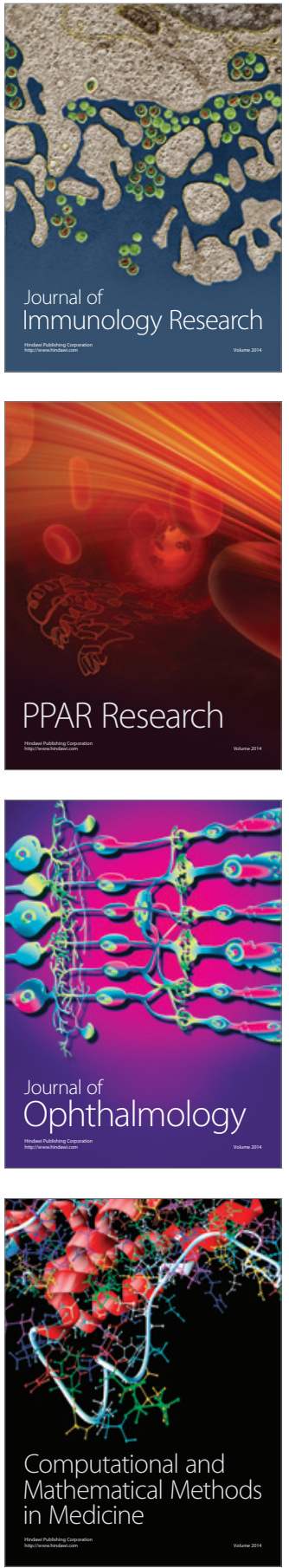

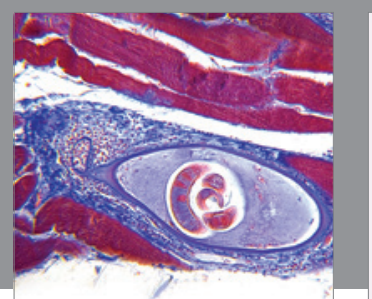

Gastroenterology Research and Practice

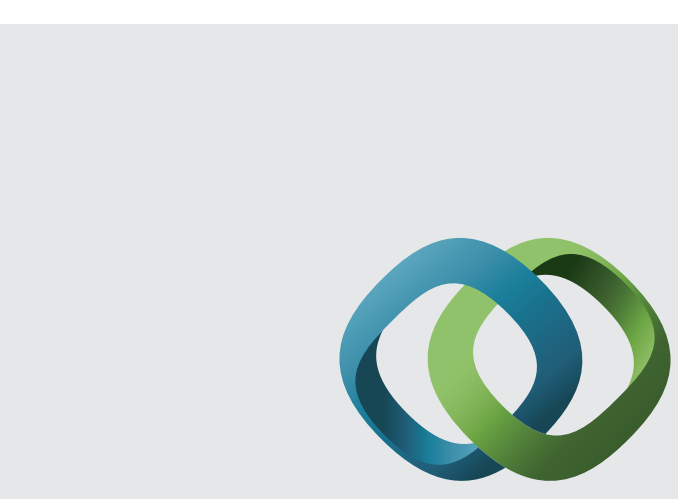

\section{Hindawi}

Submit your manuscripts at

http://www.hindawi.com
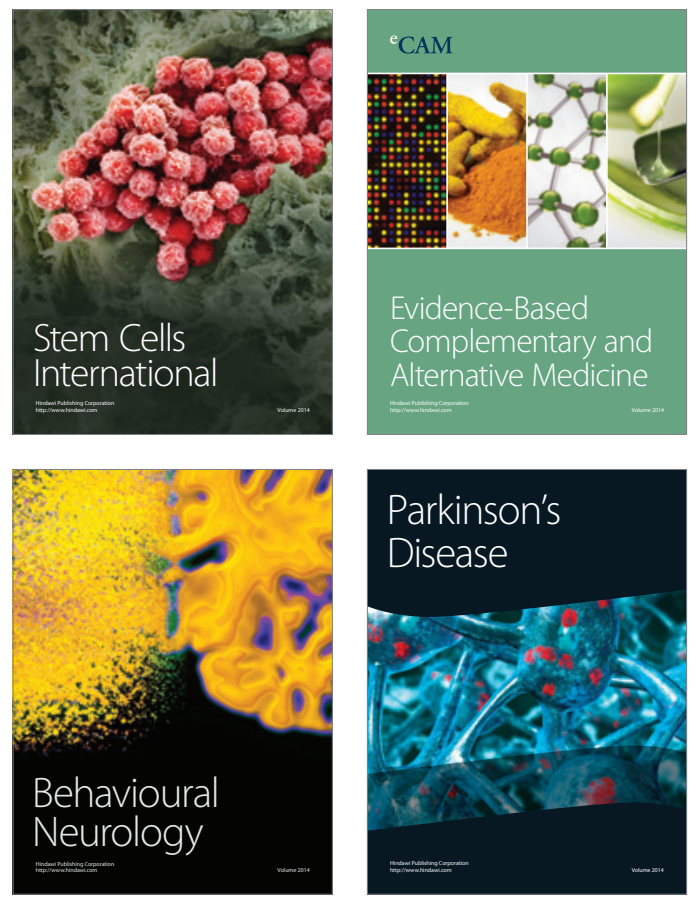
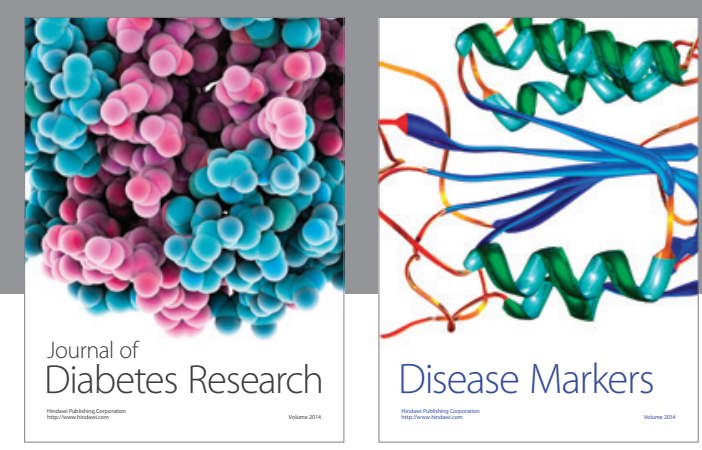

Disease Markers
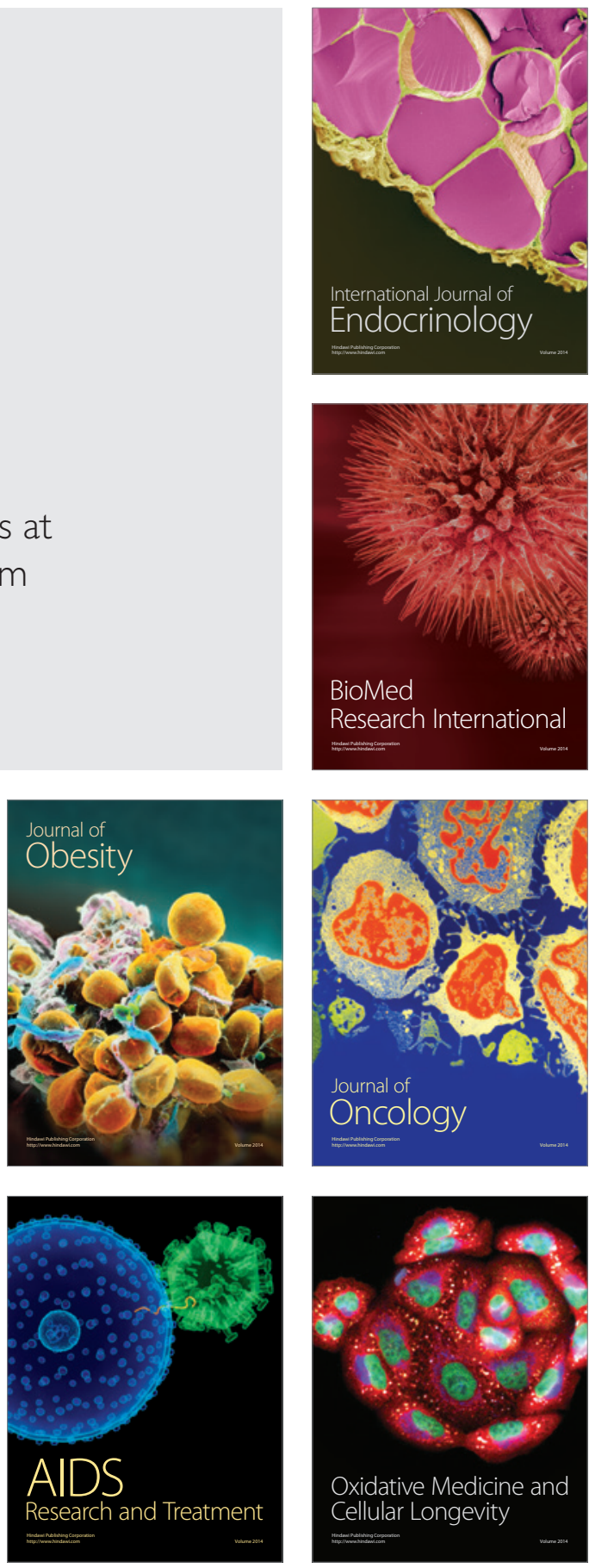